\title{
Yüksek Çözünürlüklü CCSM4 Model Verilerine Göre Son Buzul Maksimumunda (SBM) Türkiye'nin Holdridge Ekolojik Bölgeleri ve Günümüz İklim Şartlarıyla Karşılaştırılması
}

\author{
Holdridge Ecological Zones of Turkey in Last Glacial Maximum (LGM) using \\ High Resolution CCSM4 Model Data and Comparison of Current Climate \\ Conditions
}

Erkan Yılmaz ${ }^{* a}$

\begin{tabular}{l} 
Makale Bilgisi \\
\hline Araştırma Makalesi \\
\hline DOI: \\
10.33688/aucbd.880675 \\
\hline Makale Geçmişi: \\
Geliş: 28.02 .2021 \\
Kabul: 05.07.2021 \\
\hline Anahtar Kelimeler: \\
CCSM4 model verileri \\
ERA-Interim verileri \\
Yağış rejimi farkları \\
İklimsel karşılaştırma \\
Holdridge ekolojik \\
bölgeleri
\end{tabular}

Article Info

Research Article

DOI:

10.33688/aucbd.880675

Article History:

Received: 28.02 .2021

Accepted: 05.07.2021

Keywords:

CCSM4 model data

ERA-Interim data

Precipitation regime

difference

Climatic comparison

Holdridge ecological zones

\begin{abstract}
$\ddot{O} z$
Bu çalışmada, CCSM4 ve ERA-Interim model verileri kullanılarak, Türkiye'de Son Buzul Maksimumu (SBM)'de ve günümüzdeki Holdridge ekolojik bölgeleri (HEB) oluşturulmuş-karşılaştırılmış, CCSM4 verilerine göre SBM'deki iklim özellikleri ortaya koyulmuştur. Analiz sonuçlarına göre SBM'deki sicaklıkların günümüze göre farkları Karadeniz çevresinde düşükken, Türkiye'nin güneyine ve karasal iç bölgelerine doğru artmaktadır. SBM'deki yă̆ışlar, yüksek dağlık alanlarda (Güneydoğu Toroslar hariç) günümüze göre yüksek, Doğu Anadolu Bölgesi ve deniz klyılart ile alçak alanlarda düşüktür. HEB sınıflandırmasına göre Türkiye'de SBM'de alçak irtifa koşulları ortadan kalkmakta, dağllk, alpin ve karlı kat genişlemektedir. SBM'de Türkiye'de daha nemli (buharlaşma yağış oranı) koşullar oluştuğu, bu nemliliğin hem sicaklık düşüşüne bağlı buharlaşma azalmasından hem de yağış artışından kaynaklandığı anlaşılmıştır. SBM'de Türkiye'de günümüzde bulunan çöl çalılığl ve dikenli çalılık biyomlarl görülmezken, dikenli step, step ve kurak orman biyomu alanları daralmış, diğer biyom alanları genişlemiştir. Çalışma sonucunda CCSM4 verilerinin, Türkiye'nin doğu yarısı için tutarlı, batı yarısı için yarı-tutarlı olduğu görülmüştür.

Abstract

In this study, Holdridge ecological zones (HEZ) were created and compared for current and Last Glacial Maximum (LGM) time using CCSM4 and ERAInterim model data, and then climatic conditions of Turkey in LGM was analyzed using CCSM4 data. According to the results, the temperature difference in LGM compared today was low around the Black Sea while it increases at south and terrestrial of Turkey. Precipitation in LGM is high at mountain regions (exclude Southwestern Taurus Mountains) while it is low in coastal and low altitude and Eastern Anatolian Regions. According to HEZ results, lower montane is not defined at LGM but montane, sub alpine, alpine and nival conditions expanded. In LGM, more humidity conditions (ratio of evaporation and precipitation) was formed in Turkey connected increasing precipitation and especially decreasing evaporation. Desert scrub and thorn woodland are not defined in LGM, thorn steppe, steppe, dry forest biomes were narrowed while other biome areas were enlarged. In conclusion, it is obtained that CCSM4 data is suitable for eastern half of Turkey, but it is not usable for western half.
\end{abstract}

\footnotetext{
*Sorumlu Yazar/Corresponding Author: eryilmaz@ankara.edu.tr

a Ankara Üniversitesi, Coğrafya Bölümü, Ankara/Türkiye, http://orcid.org/ 0000-0002-3821-3648.
} 


\section{Giriş}

Senozoik içerisinde yer alan Kuaterner 2,6 milyon yıl önce başlamakta ve sicak-soğuk dönemlerin birbirini takip ettiği Pleistosen ve son buzularası dönem olan Holosen'den oluşmaktadır (Cohen ve Gibbard, 2019). Pleistosen döneminde, yörünge dışmerkezlik değişimi (eccentricity), eksen eğikliği değişimi (obliquity) ve yalpa hareketine (precession) bağl1 olarak gerçekleşen soğuma ve 1sınma dönemleri, küresel çapta tüm ortamların değişmesine neden olmuş, soğuk dönemlerde buzullar genişlemiş, deniz seviyesi alçalmıştır, buzularası dönemlerde tersi durum yaşanmıştır (Berger vd., 2016). Kuaterner, derin deniz sondajlarından elde edilen izotop yaşlarına bağlı olarak MIS (Marine isotope stages-denizel izotop dönemleri) dönemlerine ayrılmış ve her dönem MIS+sayı olarak belirtilmiştir (Lisiecki ve Raymo, 2005). Son buzularası dönem olan MIS5 (Eamien)'den (130-75 bin y1l (by)) sonra MIS4 (74-61 by), MIS3 (59-24 by-nispeten sıcak) ve MIS2 (23-14 by) dönemlerini kapsayan son buzul dönemi gerçekleşmiş, bu dönemin son safhası ise Son Buzul Maksimumu (SBM21 by önce) olarak tanımlanmıştır.

SBM'de tüm dünyadaki sıcaklıklar düşmüş, yağış paterni ve miktarı değişmiş, basınç ve rüzgar sistemlerinde değişim-büyüme-küçülme-yer değiştirmeler yaşanmıştır (Brauer vd., 2008). Kutuplarda ve rakımı yüksek bölgelerde oluşan buzullar, suyu depo etmiş, deniz seviyesi alçalmış, klimatolojik ve jeomorfolojik süreçler farklı işlemiştir. Bu dönemde tüm bitki örtüsü kutuplardan ekvatora ve yüksekten alçağa doğru göç etmiş ve soğuğa dayanıklı türler hâkim duruma gelmiştir (Atalay, 1994; Cox vd., 1977; Erinç, 1977). Canlılar, varlıklarını sürdürebilmek için ortam bulabildikleri yerlere sığınmıştır. Günümüz biyoçeşitlilik özellikleri bu isınma-soğuma dönemlerinin bir sonucu olarak ortaya çıkmıştır (Svenning ve Skov, 2004). SBM'de iklimsel değişkenlerle birlikte toprak oluşum-gelişim süreçleri (Atalay, 1996) de değişmiştir.

SBM dönemine ait ortam koşullarının belirlenmesi, ancak paleoklimatolojik verilerle mümkün olabilmekte, bu veriler ise çeşitlilik göstermektedir. Derin deniz sondajları (Fairbanks, 1989; Ruddiman vd., 1986) ve buzul sondajlarından (Fuhrer vd., 1999; Jouzel vd., 2007; Petit vd., 2013) elde edilen sediment ve izotop-element analiz sonuçları bulunmakta, bu veriler küresel çaptaki ortam değişimi hakkında bilgi verebilmektedir. Bunların yanında fosil polen, fosil diyatome, damlataş, ağaç halkası analizleri de geçmiş iklim bilgileri hakkında fikir vermekte, bölgesel ölçekte değişiklikler açısından daha ayrıntılı bilgiler sunmaktadır. En yaşıı ağacın 4700 yaşında olması (Roberts, 2014: 21), SBM için ağaç halkası analizlerinin yetersiz kalmasına neden olmakta, daha sonraki dönemler için önemli veriler sunmaktadır.

Polen analizleri, SBM'deki ortam koşullarının belirlenebilmesinde sıklıkla başvurulan bir yöntemdir (Tarasov vd., 2000). Türkiye'de çok sayıda fosil polen çalışması bulunmakta, çalışmaların büyük bir bölümü ancak günümüz ile Orta Holosen arası dönemi analiz edebilmektedir (Eastwood vd., 1999; Şenkul vd., 2018; Ozalp vd., 2017). Örneklerin bir kısmında alınan karotlar, daha uzun dönem için polen analizlerine izin vermekte (Mudie vd., 2007; van Zeist vd., 1975), SBM'deki ortam da belirlenebilmektedir. 
Fosil diyotomeler de SBM'deki ortam koşullarının belirlenmesinde kullanılan, ortamdaki tuzluluk, derinlik, sıcaklık gibi özelliklerdeki değişimi veren önemli bir analiz yöntemidir. Türkiye'nin belli bölgelerinde fosil diyatome analizleri yapılmış (Kashima, 2002, 2003; Paillès vd., 2014), bu analizler ise daha çok su ortamlarındaki değişimler hakkında bilgiler sağlamıştır.

Kuaterner dönemi içerisinde, Türkiye'deki dağlik alanlarda buzullaşmalar meydana gelmiş, buzulların oluşturdukları şekillere bağlı olarak paleobuzul sahaları ortaya koyulmuştur. Doğu Karadeniz Dağlarında (Doğu vd., 1996; Doğu vd., 1993; Gürgen, 2003, 2006, 2009, 2015, 2016, 2019), Orta Toroslarda (Çiner ve Sarıkaya, 2017; Gürgen vd., 2010, 2012), Batı Toroslarda (Doğu, 1993; Sarıkaya vd., 2014; Sarıkaya vd., 2008; Sarıkaya vd., 2017), Güneydoğu Toroslarda (Bayrakdar vd., 2015; Yeşilyurt vd., 2018) ve volkanik dağların yüksek kesimlerinde (Kurter, 1991; Sarıkaya vd., 2009; Zahno vd., 2010) buzul şekilleri tanımlanmış, geçmiş dönemde bu sahaların buzul ile kaplı olduğu belirlenmiştir. Bu sahaların bir kısmında kozmojenik tarihlendirme yöntemi kullanılarak, buzullaşmanın SBM'de oluştuğu, sonraki dönemlerde de buzul ilerlemelerinin olduğu anlaşılmıştır.

SBM'de Türkiye'deki ortam koşullarını derleyen çalışmalar da bulunmakta (Atalay, 1992, 2005; Çiner ve Sarıkaya, 2013; Şenkul ve Doğan, 2013) bu çalışmalar ise yeterli örnek noktasının bulunmaması nedeniyle SBM hakkında genel fikir vermektedir.

SBM'de ortam koşulları, peleoklimatolojik çalışmaların yanında, klimatolojik-matematiksel modellerle de belirlenmeye çalışılmaktadır. Bu modeller içerisinde Amerika Birleşik Devletleri Ulusal Çevre Tahmin Merkezi ekiplerince oluşturulan CCSM4 (The Community Climate System ModelTopluluk İklim Sistemi Modeli) (Gent vd., 2011), Çin Bilimler Akademisi ekipleri tarafından geliştirilen FGOALS (Flexible Global Ocean-Atmosphere-Land System-Esnek Küresel Okyanus-Atmosfer-Kara Sistemi) (Zheng ve Yu, 2013), Fransa Meteoroloji Araştırmaları Merkezi ekiplerince geliştirilen CNRM-CM5 (CentreNational de Recherches Me'orologiques, Coupled Model-Ulusal Meteoroloji Araştırma Merkezi-Birleşik Model) (Voldoire vd., 2013), Pierre SimonLaplace Enstitüsü (Fransa) tarafindan geliştirilen IPSL-CM5A (TheInstitut Pierre Simon Laplace-Coupled Model Intercomparison Project- Pierre SimonLaplace Enstitüsü, Birleşik Model Karşılaştırma Projesi) (Dufresne vd., 2013), Japonya Meteoroloji Araştırma Merkezi ekiplerince geliştirilen MRI-CGCM3 (Meteorological Research Institute Coupled Global Climate Model Version Three-Meteoroloji Araştırma Enstitüsü, Birleşik Küresel İklim Modeli Üçüncü Versiyonu) (Yukimoto vd., 2012), yine Japonyalı ekiplerce geliştirilen MIROC-ESM (Model for Interdisciplinary Research on Climate, Earth System Model-İklim Üzerine Disiplinlerarası Araştırmalar için Model, Yer Sistemi Modeli) (Watanabe vd., 2011) ve Max Planck Enstitüsü (Almanya) ekiplerince geliştirilen MPI-ESM-P (Max-Planck-Institute Earth System Model- Max Planck Enstitüsü Yer Sitem Modeli) (Jungclaus vd., 2013) modeli bulunmaktadır. Bu modellerin veri çözünürlükleri düşük olmakla beraber, genel bir iklim değişimi bilgisi sunmayı amaçlamakta, özellikle geliştirilen bölge için makul tahminler sunmaktadır. Her modelin Türkiye ve çevresi için öngörüleri oldukça büyük farkl1lıklar göstermektedir.

Bu çalışmada, CCSM4 iklim modeli verileri kullanılarak Türkiye'de SBM'deki ortam koşulları, Holdridge ekolojik bölgeleri (HEB) oluşturularak incelenmiştir. Çalışmada, Karger vd. (2017) tarafından çözünürlüğü artırılmış ERA-Interim (Dee vd., 2011) verileri kullanılarak oluşturulmuş 
günümüz HEB sınıfları (Yılmaz, 2021) ile SBM'deki ortam koşulları da karşılaştırılmışıtır. Çalışmada ayrıca aylık ortalama sıcaklık ve aylık toplam yağış miktarları karşılaştırılmış, aralarındaki farklar belirlenmiş, yağış ve sıcaklık rejimlerindeki değişimler ortaya koyulmuştur.

\section{Veri ve Yöntem}

2.1. Veri

Çalışmada, güncel durumu temsil etmesi amaciyla, 1979-2013 dönemi ERA-Interim verilerinin (Dee vd., 2011) Karger vd. (2017) tarafından çözünürlüğü artırılmış versiyonu kullanılarak oluşturulmuş HEB sınıfları (Yılmaz, 2021) ile SBM'yi temsil eden, Gent vd. (2011) tarafindan oluşturulmuş ve yine Karger vd. (2017) tarafından çözünürlüğü artırılmış CCSM4 verileri kullanılmıştır. SBM için başka model verileri de bulunmakta, CCSM4 verileri hem küresel ölçekte (Brady vd., 2013; Feng vd. 2017; Gent vd, 2011; Meehl ve Arblaster, 2011) hem de Türkiye'de (Çoban, Örücü ve Arslan, 2020; Sarıkaya vd., 2018) daha sık kullanılmaktadır. Çalışmada 1 km çözünürlüklü aylık ortalama sıcaklık ve aylık toplam yağış verileri değerlendirilmiş ve HEB sınıflandırması yapılmıştır.

\subsection{Yöntem}

Çalışmada, günümüz ve SBM'de iklim özellikleri değerlendirilmiş, aylık ortalama sıcaklık ve aylık toplam yağış verilerindeki farklılıklar incelenmiş, rejim farkları ortaya koyulmuştur. Bu amaçla, ilk olarak, günümüze göre SBM'deki yıllık ortalama sıcaklık farkları belirlenmiş, aylar arasındaki farklılığı belirtmek amacıyla, her noktada ( 800 bin nokta), $0^{\circ} \mathrm{C}^{\prime}$ dan düşük ay sayıları haritalanmıştır.

Günümüz ve SBM'deki yıllık toplam yă̆gş farklarındaki değişim, fark değerlerinin günümüz ortalamalarına oranlanmasıyla verilmiş, ayrıca her noktadaki yağış rejimi incelenmiştir. Yağış rejimi incelenirken, aylık değerlerdeki salınımları ifade etmesi amacıyla zirve sayıları belirlenmiştir. $\mathrm{Bu}$ hesaplamada herhangi bir ayın yağışı kendinden önceki ve sonraki aydan yüksekse zirve olarak değerlendirilmiş, yıl boyunca işlem tekrar edildiğinde, Türkiye'de zirve sayısının 1-5 arasında olduğu görülmüş hem günümüz hem de SBM için tüm noktaların zirve sayıları haritalanmıştır.

Çalışmada ayrıca sıcaklık ve yağış şartlarının günümüz ve SBM'deki durumu incelenmiş, grafiksel gösterimler oluşturulmuştur. Bu amaçla, Türkiye'de, her bölgeden, alçak-yüksek yerleri, ovaları-dağlık alanları, denizel-karasal bölgeleri yansıtacak şekilde100 nokta seçilmiş, aylık ortalama sıcaklık ve aylık toplam yağış grafikleri haritalanmış ve karşıllaştırılmıştır.

Çalışmanın ikinci bölümünde, iklim sınıflarının belirlenmesi amacıyla HEB sınıflandırması kullanılmıştır (Holdridge, 1947). Holdridge tarafindan oluşturulan ekolojik sınıflar, günümüz koşullarına göre, Kuzey Amerika için oluşturulmuştur. Bu nedenle, Kuzey Amerika dışında ve farklı iklimsel (örneğin SBM) koşullar için uygulandığında grafik üzerinde bazı bölgelerin henüz tanımlanmadığı görülmüştür. Eksiklikler bu çalışmada giderilmeye çalışılmış, Türkiye için SBM'deki sahaların tanımı yapılmıştır (Şekil 1). Tüm iklim değişkenlerinin değiştiği bir dönem için (SBM) bu sınıflandırmanın yetersiz kalması beklenen bir durumdur ve ancak yeni tanımlamalarla kullanışı hale gelebilmiştir. 
Çalışmada, mekânsal tanımlamalar yapılmış, bulgular bölümünde sunulmuştur. Ayrıca, Türkiye'deki tüm noktaların grafiğe yerleştirilmesi ve dış sınırının çizilmesi ile HEB izi elde edilmiş, bu izin günümüz ve SBM'de değiştiği görülmüştür (Şekil 1). SBM'de Türkiye HEB izi günümüze grafikte daha yukarı çıkmış ve sağ-sol genişliği azalmıştır. Çok soğuk sahalar grafiğin üst kısmına doğru uzamış, iki hat olarak ortaya çıkmıştır. Bu uzanışlardan yukarıda olan, Ağrı ve Süphan gibi yüksek, yağışı nispeten düşük sahaları, aşağıda olan ise Doğu Karadeniz Dağları gibi yüksek yağışlı sahaları göstermektedir.

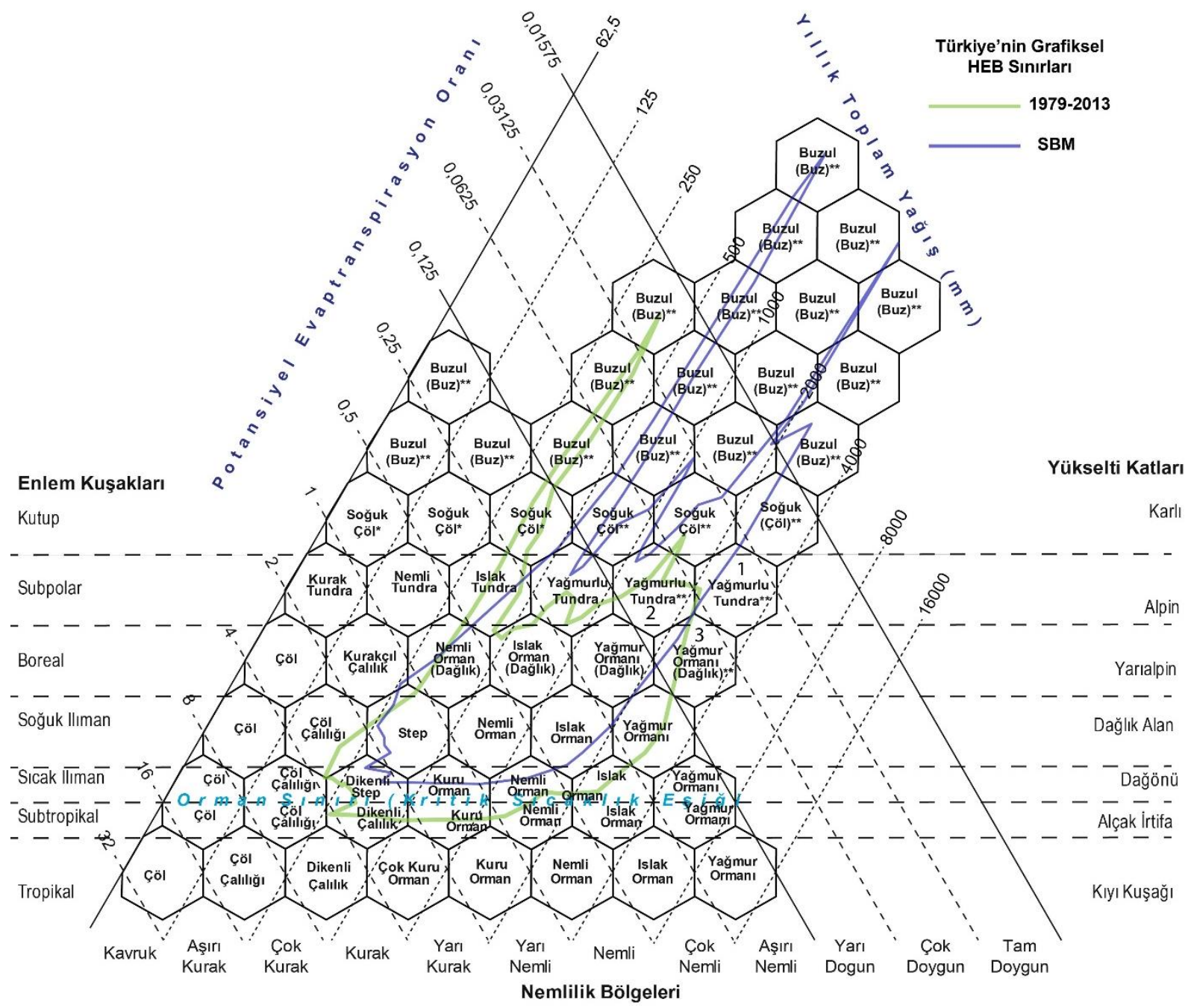

Şekil 1. HEB sınıflandırma grafiği ile Türkiye'nin güncel ve SBM'deki HEB izi. 1, 2 ve 3 numaralı yağmurlu tundra ve dağlik yağmur ormanları kesin değildir, buzul sahası olabilirler.

HEB yönteminde potansiyel evapotranspirasyon (PE) değerleri kullanılmakta, bu değer 0-30 ${ }^{\circ} \mathrm{C}$ arası için hesap edilmektedir. SBM'de bazı noktalar (örneğin Ağr1 Dağı zirvesi) yıl boyunca $0{ }^{\circ} C^{\prime} 1 n$ altında sıcaklığa sahip olduğundan, bu sahalarda PE değeri hesap edilememiştir. Bu nedenle grafikte tanımı mümkün olmamaktadır. Çalışmada bu sahalar, karlı, tam doygun, buzul sahası olarak tanımlanmıştır.

$\mathrm{Bu}$ çalışmada, Türkiye sınırları içerisinde kalan günümüz kara alanları değerlendirilmiştir. SBM'de küresel deniz seviyesinin -120'de olduğu bilinmekte (Clark ve Mix, 2002; Fleming vd., 1998), 
bu durumda kara sınırları değişmektedir. Türkiye için SBM'deki kara sınırlarının belirlenmesi, Marmara (Londeix vd., 2009) ve Karadeniz (Major vd., 2006) göllerinin sınırlarına bağlı da değişmektedir. Çalışmada, günümüz ve SBM iklim özelliklerinde farklılıklar incelenmiş, göl ve deniz seviyesine bağlı kara sınırı değişimleri, konu ile ilişkili olduğunda değerlendirilmiştir.

Çalışmada üretilen Holdridge ekolojik bölgeleri haritalarının vektör formatları, http://geography.humanity.ankara.edu.tr/turkiye-iklim-arastirmalari/ sitesinden indirilebilir.

\section{Bulgular}

\subsection{SBM'de Klimatolojik Değişkenlerdeki Farklılıklar}

Bu kısımda, günümüz ve SBM'deki aylık ortalama sıcaklık ve aylık toplam yağış verilerindeki farklılıklar değerlendirilmiş, rejimlerdeki değişimler incelenmiştir.

\subsubsection{SBM'deki Sicaklık Özellikleri}

CCSM4 verilerine göre SBM'de yıllık ortalama sıcaklar günümüze göre düşük olmasına rağmen, sıcaklık farkları bölgelere göre değişmektedir. Yıllık ortalama sıcaklık farkları Karadeniz çevresinde düşükken (Şekil 2), Türkiye'nin güneyine doğru yükselmekte, en yüksek farklar denizden uzak iç bölgelerde karşımız çıkmaktadır. En yüksek sıcaklık farkları Tuz Gölü çevresi ve Güneydoğu Anadolu Bölgesinde belirlenmiş, bölgedeki farklar $10^{\circ} \mathrm{C}^{\prime} 1$ geçmiştir. Nemli olan Karadeniz çevresine yaklaştıkça sıcaklık farkları düşmekte, $1{ }^{\circ} \mathrm{C}$ 'a kadar inebilmektedir.
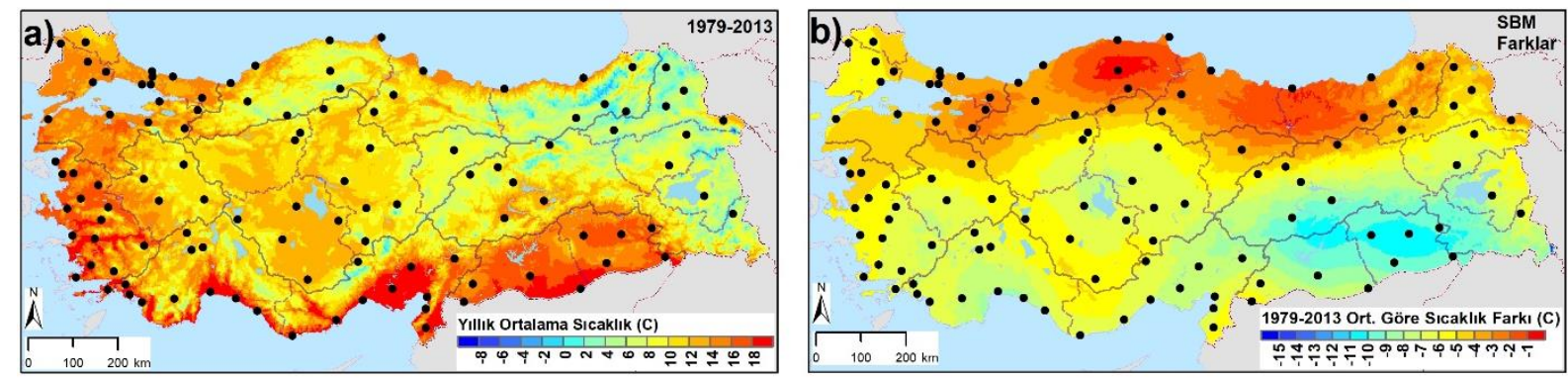

Şekil 2. ERA-Interim verilerine göre günümüzde yıllık ortalama sıcaklıklar (a) ileCCSM4 verilerine göre SBM'deki yıllık ortalama sicaklıklarının günümüze göre farkları

Türkiye'de günümüzde tek zirveli (en yüksek sıcaklık temmuz-ağustos ayında), kuzey yarım küre, orta enlem sıcaklık rejimi hâkimdir (Şekil 3a). Bu sıcaklık rejimi Türkiye'de 2 ana gruba ayrılmakta, bu grupların ilkinde sıcaklık yıl boyu $0{ }^{\circ} \mathrm{C}^{\prime} 1 n$ üzerinde, ikincisinde ise bir ayda $0^{\circ} \mathrm{C}$ 'a eşit ya da en az bir ay $0^{\circ} C^{\prime}$ 'n altında seyretmektedir. Türkiye'de genel olarak, Akdeniz, Ege, Marmara ve Karadeniz kıyıları ile yükseltisi düşük plato ve yamaçlar ile vadilerde aylık ortalama sıcaklıklar yıl boyu $0{ }^{\circ}$ '’n üzerindedir (Şekil 3b). SBM'de ise aylık ortalama sıcaklıklar sadece Akdeniz, Ege, Marmara ve Karadeniz kıyılarında birinci grup sıcaklık rejimi özelliğindedir ve bu sahalardaki sıcaklıklar yıl boyu $0^{\circ} \mathrm{C}$ 'ın üzerinde seyretmektedir (Şekil 3c). $0^{\circ} \mathrm{C}$ 'ın altındaki ay sayısı günümüzde Doğu Karadeniz Dağlarının zirvelerinde 6-7 ay olabilirken, 10 ay olduğu tek yer Ağrı Dağı zirve çevresidir. SBM'de ise aylık ortalama sıcaklıklar Doğu Anadolu Bölgesinin büyük bölümünde 8-9 ay 0 ${ }^{\circ} C^{\prime} 1 n$ altında kalmakta, Ağrı Dağında ise yıl boyu $0{ }^{\circ} C^{\prime} 1 n$ altında seyretmektedir. 

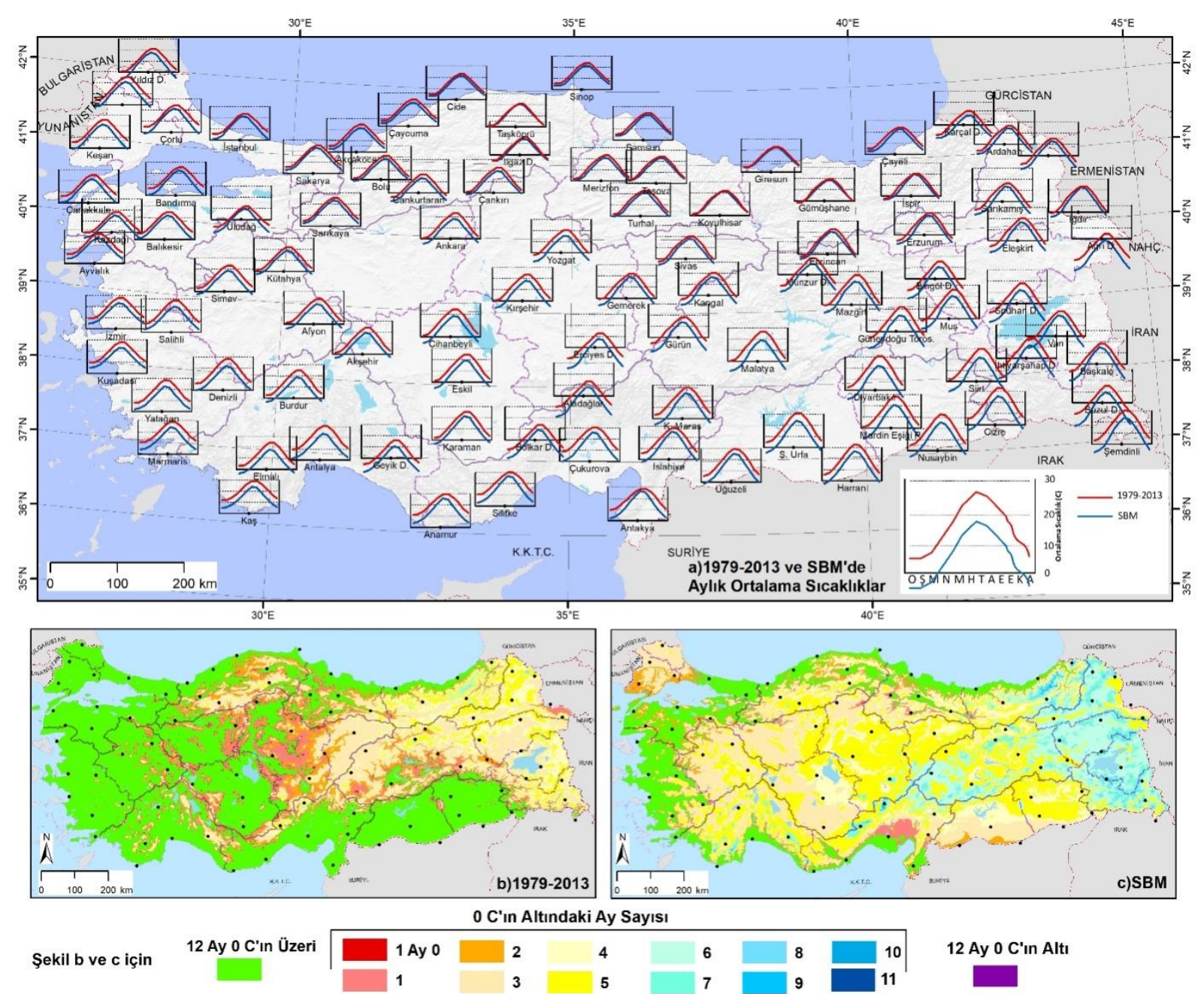

Şekil 3. Günümüz (1979-2013) ve SBM'de aylık ortalama sıcaklıklar (a), günümüzde Türkiye'de sıcaklığın $0{ }^{\circ} \mathrm{C}$ 'ın altında olduğu ay sayıları (b), SBM'de Türkiye'de sıcaklığın $0{ }^{\circ} C^{\prime}$ 'n altında olduğu ay sayıları (c).

Model verilerine göre Karadeniz çevresindeki günümüz aylık ortalama sicaklıkları ile SBM'deki ortalama sıcaklıklar arasındaki fark yıl boyunca düşüktür (Şekil 3a). Yıl içindeki sıcaklık farkları Türkiye'nin güneyine doğru artmaktadır. Günümüz ve SBM'de sıcaklık farkları, Türkiye'nin büyük bir bölümünde, özellikle Orta Toroslar ve Adana Bölümünde yaz aylarında azalmakta, kış aylarında yükselmektedir. Günümüzde Ağrı Dağı zirvesi çevresinde sıcaklıklar sadece temmuzağustosta $0^{\circ} \mathrm{C}^{\prime}$ ’n üzerine çıkmaktayken, SBM'de y1l boyu $0^{\circ} \mathrm{C}$ 'ın altında kalmaktadır (Şekil 3a-c).

Türkiye'de günümüz ortalamalarına göre, aylık ortalama sıcaklıkların en yüksek olduğu ay, Karadeniz ve Akdeniz kıyıları ile Anadolu Diyagonali çevresinde ağustos, diğer sahalarda ise temmuz ayına denk gelmektedir (Şekil 4a). Model verilerine göre SBM'de bu durum değişmekte, Trabzon ve çevresindeki sahalarda en sıcak dönem ağustos, diğer bölgelerde ise temmuz ayına denk gelmektedir (Şekil 4b). 

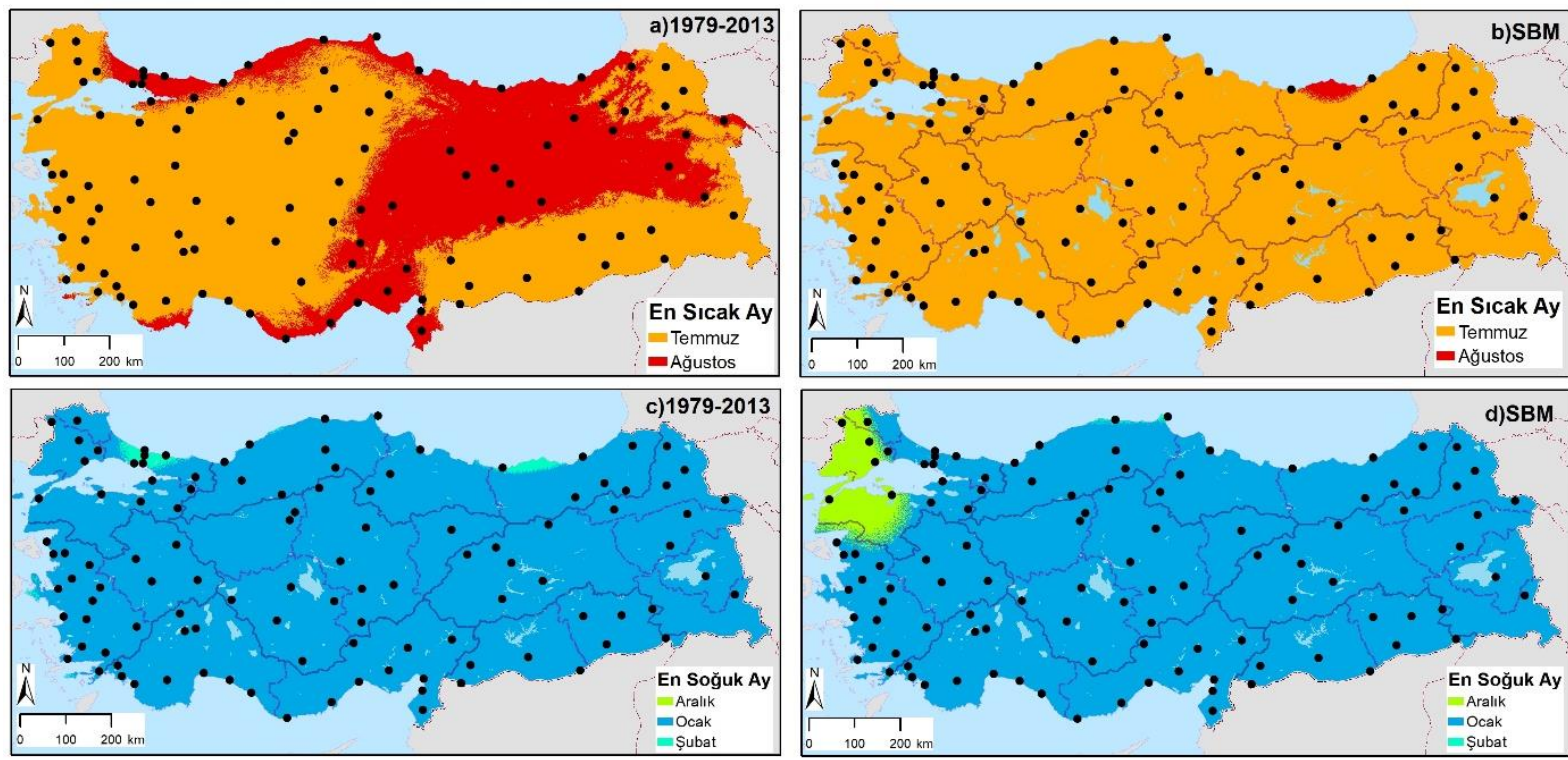

Şekil 4. Günümüz ve SBM'de aylık ortalama sıcaklığın en yüksek ve düşük olduğu aylar.

Günümüzde en düşük aylık ortalama sıcaklıklar, İstanbul Boğazı çevresi, Datça Yarımadası, Ege kıyılarında ve Trabzon çevresinde şubat, diğer sahalarda ise ocak ayında yaşanmaktadır (Şekil 4c). Model verilerine göre SBM'de en soğuk ay, Trakya batı yarısı ile Biga Yarımadası kuzeyinde aralık, Sinop-İnebolu arasındaki kıyılarda şubat, Türkiye'nin diğer bölgelerinde ise ocakta karşımıza çıkmaktadır (Şekil 4d).

\subsubsection{SBM'deki Yağış Özellikleri ve Rejim Farklılıkları}

CCSM4 model verilerine göre SBM'de y1llık toplam yağışlar, Güneydoğu Toroslar, Doğu Anadolu Bölgesi, Tuz Gölü çevresi, Akdeniz ve Karadeniz kıyılarında günümüze göre düşüktür (Şekil 6). Van Gölü kuzey, batı ve güneyindeki yağış farklılığ $\% 30$ 'dan fazladır. Bununla beraber, Yeşilırmak Havzasının yukarı çığırı, Çoruh Havzası, Uludağ, Köroğlu ve Ilgaz Dağları, Teke Platosu ile Orta Toroslar günümüze göre daha yüksek yağışlar almaktadır.
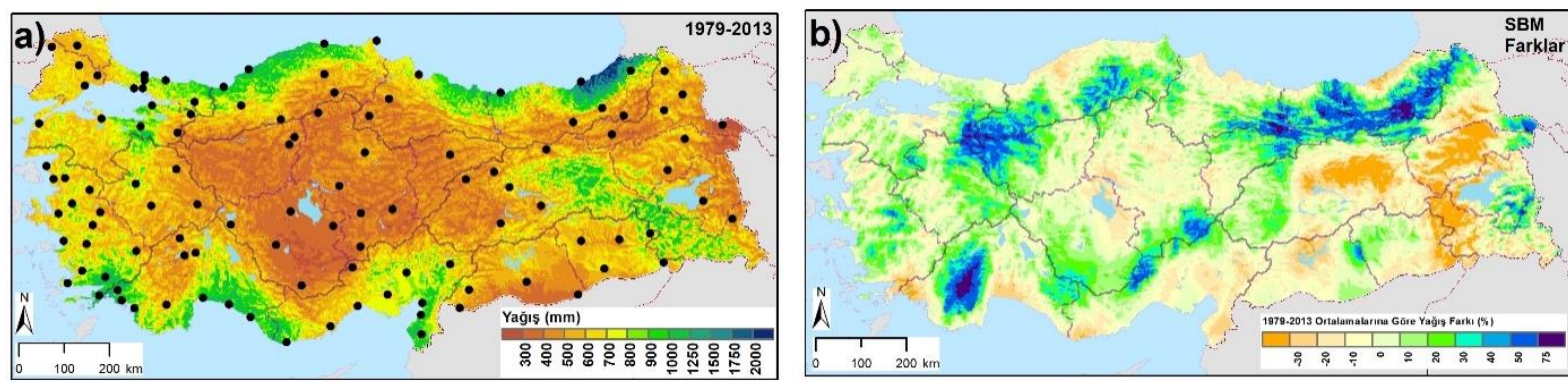

Şekil 5. ERA-Interim verilerine göre günümüzde yıllık ortalama toplam yağışlar (a) ile CCSM4 verilerine göre SBM'deki yıllık toplam yă̆ışların günümüze göre oransal farkları (b).

ERA-Interim verilerine göre Türkiye'de aylık yağış grafikleri incelenerek zirve sayıları belirlendiğinde, "tek zirveli”, “çift zirveli”, “üç, dört ve beş zirveli (çok zirveli)” yağış rejimlerinin var olduğu görülmektedir. Tek zirveli rejim, Akdeniz, Ege, Marmara denizleri kıyılarında ve Güneydoğu Anadolu Bölgesinde görülmekteyken, Doğu ve İç Anadolu Bölgeleri, Doğu ve Batı Karadeniz 
Bölümleri ile Akdeniz ve Ege Bölgelerinin yüksek kesimleri ve Ergene Havzası çevresinde çift zirveli yağış rejimi belirlenmiştir (Şekil 6a-b). Orta ve Batı Karadeniz Bölümleri ile İç Ege Bölümü platolarında ve İç Anadolu çukuru çevresinde çok zirveli, daha düzenli yağış rejimleri görülmektedir. CCSM4 model verilerine göre SBM'de bu rejim dağılışında değişimler görülmekte, tek zirveli yağģs rejimi sahası daralarak Ege ve Akdeniz çevresine sıkışmakta, Güneydoğu Anadolu Bölgesinde çift zirveli rejim hâkim olmaktadır. Çok zirveli rejim alanı genişlemekte, tüm Karadeniz çevresini kaplamakta, Orta Toroslarda da görülmeye başlamaktadır (Şekil 6c).

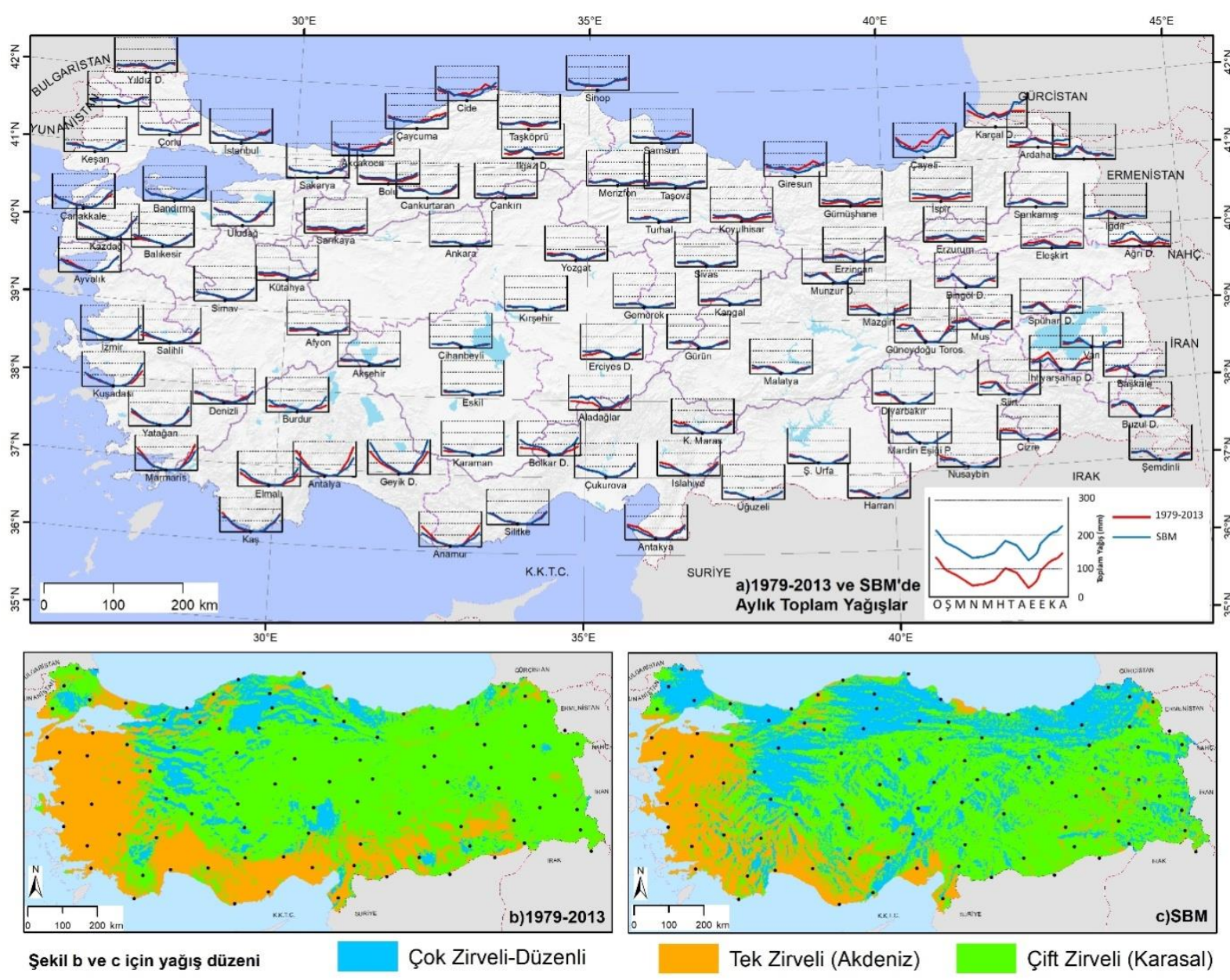

Şekil 6. Günümüz ve SBM'de aylık toplam yağışlar (a), günümüzde Türkiye'de görülen yağış rejimleri (b), SBM'de Türkiye'de görülen yağış rejimleri (c).

Aylık yağış miktarları incelendiğinde, günümüz ve SBM yağışlarının İç Anadolu, Ege ve Marmara Bölgesinde benzer özellikler gösterdiği, Akdeniz Bölgesi ve güney Ege kıyılarında kış yağışlarının günümüze göre düşük olduğu görülmektedir (Şekil 6a). Benzer şekilde Batı Karadeniz Bölümü'nde yaz, Orta ve Doğu Karadeniz'de hem yaz hem da güz yağışları günümüze göre düşüktür. Kahramanmaraş-Antakya ile Cizre çevresindeki kış yağışları günümüze göre düşükken, SBM'deki yağışlar Diyarbakır civarında daha yüksektir. Güneydoğu Anadolu Bölgesindeki yaz yağışları günümüzdekine benzer şekilde düşüktür. Van Gölü çevresindeki yağışlar yıl boyunca günümüze göre daha düşükken, Ağrı Dağı ve Erzurum çevresindeki yağışlar yıl boyunca günümüzdekinden yüksektir. 
Çoruh Vadisinde de yağışlar günümüze göre daha yüksek değerler göstermekte, artışlar kış dönemine daha belirgin görülmektedir.

ERA-Interim verilerine göre günümüzde Karadeniz, Güney Marmara, Ege ve Akdeniz kıyıları ile Güneydoğu Toroslar ve çevresi, Anadolu Diyagonalinin kuzeydoğu kısmında en kurak ay (aylık toplam yağışın en düşük olduğu ay) temmuz, Batı ve Doğu Karadeniz sahil kesiminde nisan, Kuzeydoğu Anadolu ve Gökırmak Depresyonunda ocak, Erzurum ve Gerede çevresinde eylül, Türkiye'nin geriye kalan kısımlarında ise ağustos ayına denk gelmektedir (Şekil 7a). CCSM4 verilerine göre SBM'de bu durum farkl11ıklar göstermekte (Şekil 7b), Gerede ve çevresinde en kurak ay ağustos olmakta, Güneydoğu Anadolu Bölgesinde ağustos kurak sahası daralmakta, Doğu Anadolu Bölgesinin batı yarısındaki kurak ay ağustostan temmuza kaymakta, Doğu ve Batı Karadeniz sahil kesiminde nisan ayına denk gelen kurak dönem ağustosa kaymaktadır. Karçal Dağları çevresinde ise kurak dönem martnisana kaymaktadır.
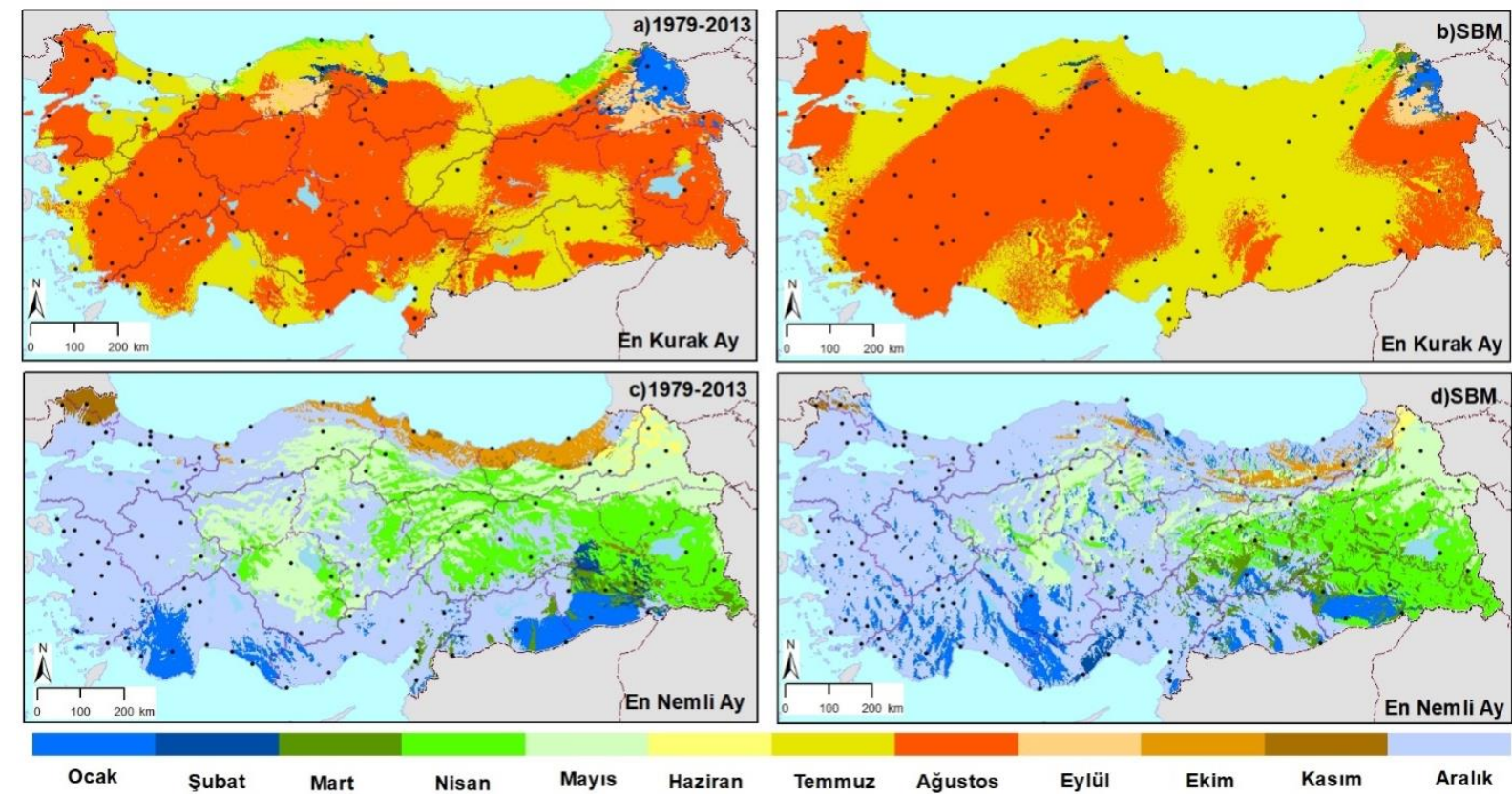

Şekil 7. Türkiye'de günümüz ve SBM'de en kurak ve en nemli aylar.

En yağışlı ay günümüz ortalamalarına göre Batı Akdeniz ve Güneydoğu Anadolu Bölgesinde ocak, Güneydoğu Torosların doğu yarısında şubat ve mart, Doğu Anadolu Bölgesi ve Yukarı Kızılırmak Bölümü ile Yeşilırmak Havzası'nda nisan, İç Anadolu Bölgesinin batı yarısı, Ilgaz Dağları çevresi ve kuzeydoğu Anadolu'da mayıs, Ardahan çevresinde haziran, Orta ve Doğu Karadeniz kıyılarında ekim, Yıldız Dağları çevresinde kasım, Türkiye'nin diğer bölümlerinde aralık ayına denk gelmektedir. SBM'de bu dağılış küçük değişiklikler göstermekte, Batı Toroslarda ocak, Mersin çevresinde şubat ayına denk gelmekte, Kuzeydoğu Anadolu'da ve İç Anadolu Bölgesinin batısında mayıs ayı sabit kalırken, Doğu Anadolu Bölgesindeki durum değişmekte, nisan ayının yerini bölgenin güneybatısında mart ayı almaktadır. Karadeniz kıyısındaki ekim yağışlı bölgesi Doğu Karadeniz dağlık alanına sıkışmakta, Yıldız Dağlarındaki kasım yağışlı bölgesi daralmakta, Türkiye'nin büyük bir bölümünde en yağışlı ay aralık olmaktadır. 


\subsection{SBM'de Türkiye'nin HEB Bölgeleri}

Bu kısımda, günümüz için Yılmaz (2021) tarafından oluşturulmuş HEB bölgeleri ile bu çalışmada CCSM4 verileri kullanılarak üretilen HEB bölgeleri karşılaştırılmış ve mekânsal farklılıkları ortaya koyulmuştur.

\subsubsection{SBM'de Türkiye'deki Yükselti ve Enlem Kuşakları}

HEB sınıflaması yükselti ekolojik katları içindeki alçak irtifa kuşağı, günümüzde (1979-2013) Türkiye'nin Güneydoğu, Akdeniz ve Ege Bölgelerinde görülmekteyken, CCSM4 modeli verilerine göre SBM'de Türkiye'de alçak irtifa kuşağı bulunmamakta (Şekil 8, Şekil 9), bu sahalarda dağönü ve dağlık kuşak yer almaktadır. Benzer şekilde günümüzde geniş alan kaplayan dağönü kuşağı SBM'de sadece Akdeniz, Ege ve Karadeniz kıyıları ile İzmit Körfezi ve Adapazarı çevresinde bulunmaktadır. SBM'deki dağönü kuşağı, günümüzdeki alanının onda birinden biraz geniştir.

Türkiye'de günümüzde en geniş alan kaplayan dağlik kuşak (yaklaşık 408 bin km²) SBM'de daha geniş bir alan kaplamakta, alanı 500 bin km²'yi geçmektedir (Şekil 8, Şekil 9). Günümüz verilerine göre Karadeniz, Akdeniz, Ege, İç ve Doğu Anadolu Bölgelerinin yüksek bölgelerini kaplayan bu kuşak, SBM'de Doğu Anadolu Bölgesi haricindeki tüm bölgelerde genişlemiş, Güneydoğu Anadolu ve Marmara Bölgesinin ise yüksek kısımlarını kaplamıştır. Doğu Anadolu Bölgesinde ise SBM'de daralma göstermiş, bu kuşağın yerini alpin ve yarıalpin kuşak almıştır.

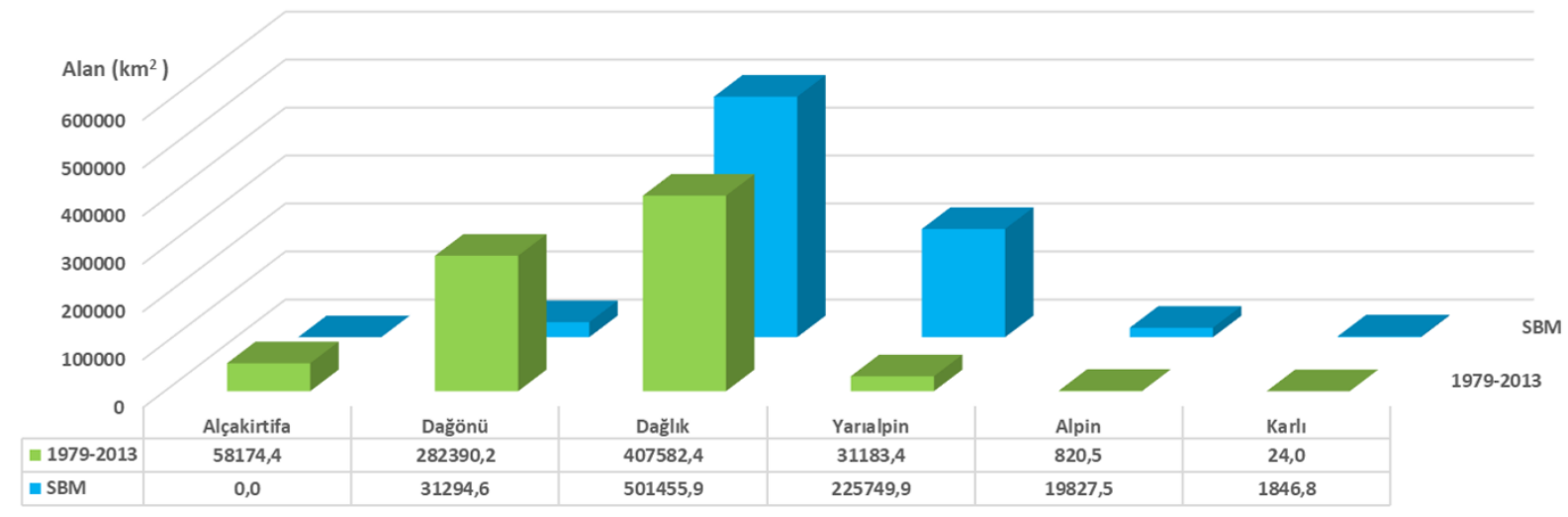

Şekil 8. HEB yükselti katlarının güncel ve SBM'deki alanları.

Günümüzde çok sınırlı bir alanda yer alan yarıalpin kuşak, CCSM4 model verilerine göre SBM'de Türkiye'nin beşte birinden daha geniş alan kaplamaktadır. Günümüzde Doğu Karadeniz, kuzeydoğu Anadolu ve Türkiye'nin 2500-3000 metre üzerindeki diğer dağlık alanlarında karşımıza çıkan bu kuşak (Şekil 9), SBM'de Doğu Anadolu Bölgesinin depresyonları haricinde neredeyse tamamını kaplamış, Akdeniz, Karadeniz ve Ege Bölgelerindeki dağlık alanlardan aşağılara doğru genişlemiştir.

Alpin kat, günümüz ortalamalarına göre Türkiye'de $800 \mathrm{~km}^{2}$ 'den biraz fazla alan kaplamakta (Şekil 8), Doğu Anadolu Bölgesi, Doğu Karadeniz Dağları ve Torosların 3000 metreden yüksek kısımlarında görülmekteyken model verilerine göre SBM'de bu katın alanı 20 bin km², ye yaklaşmakta, 2000-2500 metrelere kadar inebilmektedir. Bu kat SBM'de, Torosların, Doğu Karadeniz Dağlarının, 
Doğu Anadolu Bölgesinde yer alan dağların yüksek kesimleri ile Uludağ ve Köroğlu Dağlarının zirve çevrelerinde hâkim durumdadır.

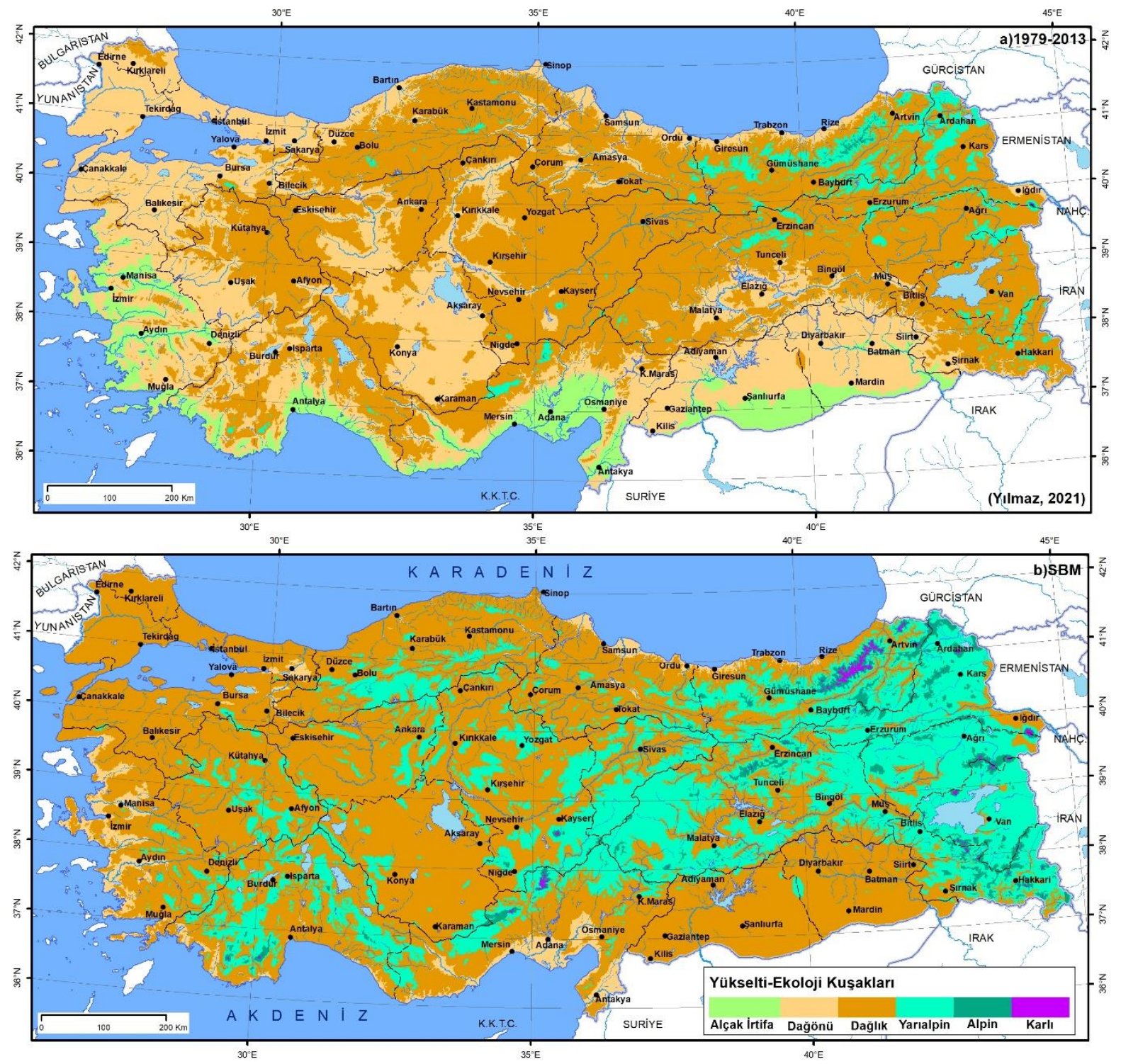

Şekil 9. HEB yükselti katlarının günümüzde ve SBM'deki dağılışı.

Türkiye'de günümüzde $24 \mathrm{~km}^{2}$ alan kaplayan karlı kat (Şekil 8), yıl boyu karla kaplı sahalardır ve sadece Ağrı Dağı ve çevresinde bulunmaktadır. Model verilerine göre bu kuşak, SBM'de oldukça geniş bir alan kaplamakta 2000 km² alana yaklaşmakta, Toroslar ve Doğu Karadeniz Dağları ile İç ve Doğu Anadolu Bölgesinde yer alan dağların zirvelerinde karşımıza çıkmaktadır (Şekil 9).

\subsubsection{SBM'de Türkiye'deki Nemlilik Bölgeleri}

1979-2013 ortalamalarına göre Türkiye'nin yaklaşık onda biri yarı kurakken, CCSM iklim modeli sonuçlarına göre bu alanlar SBM'de $1000 \mathrm{~km}^{2}$ ' den daha dar alan kaplamaktadır (Şekil 10, Şekil 11). Günümüzde, tüm bölgelerde az ya da çok görülen, İç Anadolu Bölgesinde geniş alan kaplayan yarı 
kurak sahalar SBM'de sadece Harran Ovası ve güneyinde bulunmakta (Şekil 10), günümüzde yarı kurak olan yerlerin büyük bölümü SBM'de yarı nemli özellik göstermektedir.
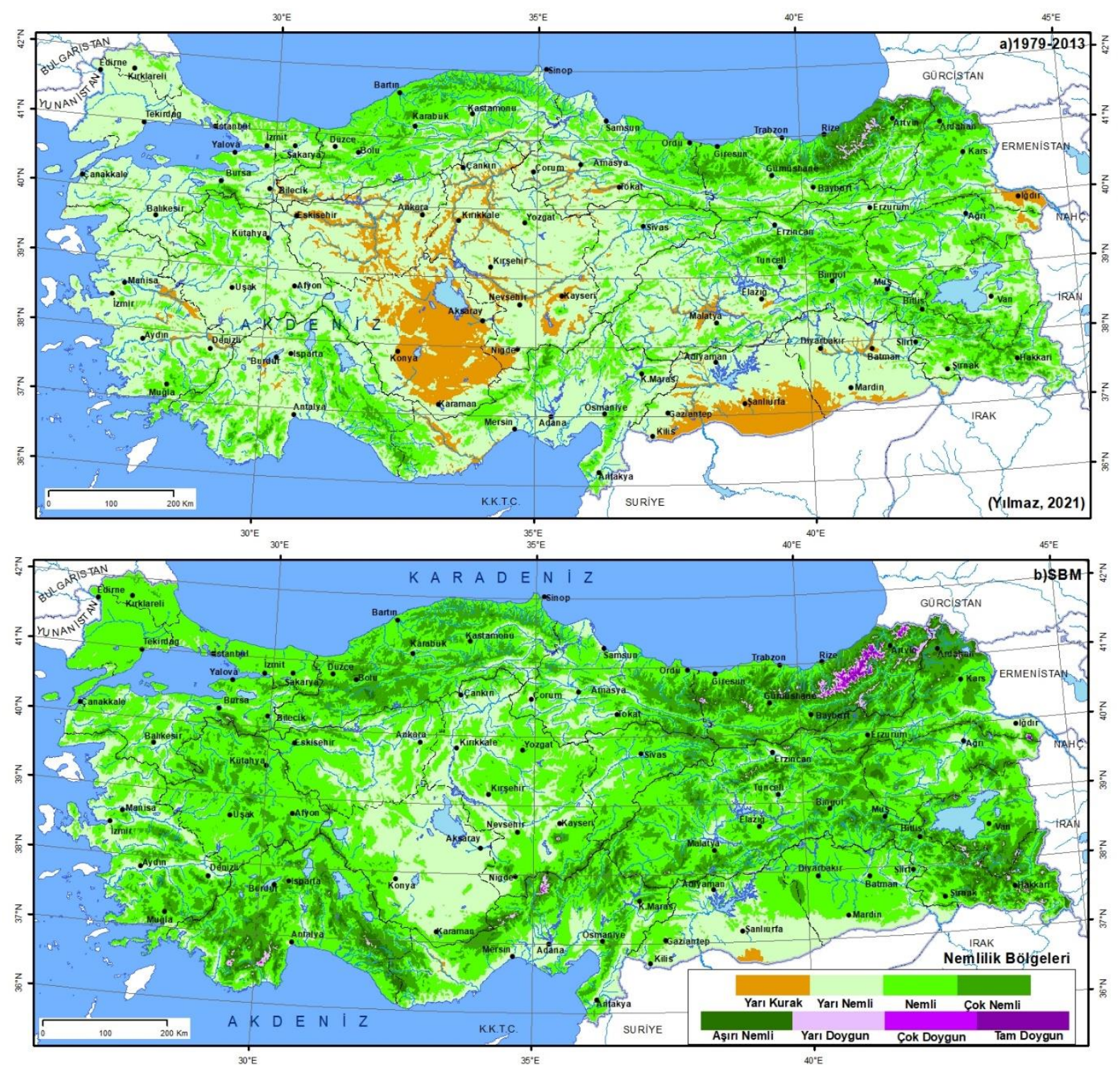

Şekil 10. HEB nemlilik bölgelerinin günümüz ve SBM'deki dağıllş̧ı.

Günümüz ortalamalara göre Türkiye'nin yarısından fazlasını kaplayan yarı nemli sahalar, model verilerine göre SBM'de Türkiye'nin dörtte birinden azını kaplamaktadır (Şekil 11). SBM'deki yarı nemli alanlar, günümüzdeki yarı kurak sahaları ve yakın çevresini kaplamakta, Bafra ve Çarşamba deltaları ise hem günümüzde hem de SBM'de yarı nemli alan özelliği göstermektedir (Şekil 10). Günümüzde İç ve Güneydoğu Anadolu Bölgesinde yüksek platolarda hâkim olan yarı nemli koşullar, SBM'de bu bölgelerin alçak plato ve ovalarında, Doğu Anadolu Bölgesinde ise depresyon tabanlarında görülmekte, Ege ve Akdeniz kıyılarında ve alçak ovalarında karşımıza çıkmaktadır.

Günümüz orman alanları ile örtüşen nemli sahalar (Yılmaz, 2021), CCSM4 model verilerine göre SBM'de Türkiye'nin yarısından fazlasını kaplamaktadır (Şekil 10, Şekil 11). Günümüzde sadece 
Karadeniz Bölgesinde deniz seviyesinde görülen nemli sahalar, SBM'de Akdeniz, Ege ve Marmara kıyılarından başlamakta, Ege, İç, Doğu ve Güneydoğu Anadolu Bölgesinin yüksek platolarında görülmektedir. Güncel verilere göre, Toroslar, Kuzey Anadolu Dağları ve volkanik dağların yüksek kesimlerinde hâkim olan çok nemli ortamlar ise SBM'de günümüzdekinin yaklaşık dört katı daha geniş bir alana yayılmakta, tüm dağların yüksek kesimlerinde karşımıza çıkmaktadır. Günümüzde 3000 $\mathrm{km}^{2}$ 'den dar alan kaplayan aşırı nemli ortamlar, Uludağ, Toroslar, Doğu Karadeniz Dağları ile Ağrı, Süphan gibi volkanik dağlarının zirve çevrelerinde görülmekteyken, SBM'de 30 bin km²,ye yakın alan kaplamaktadır.

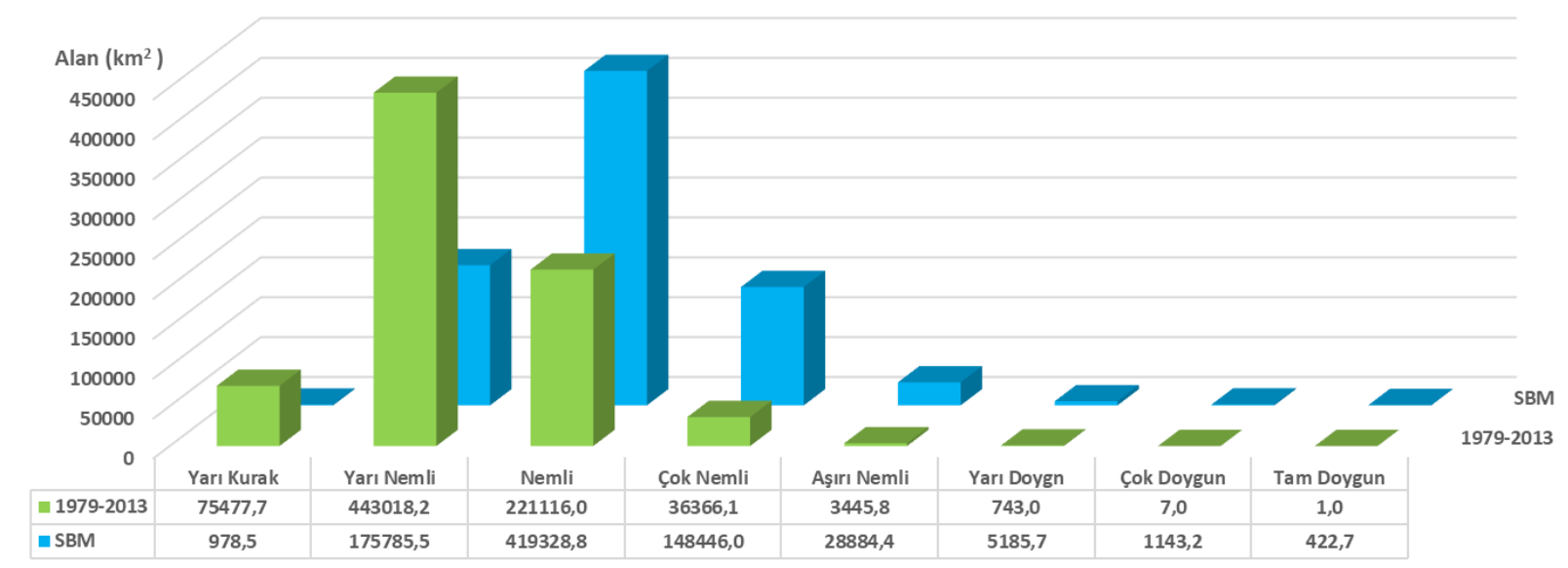

Şekil 11. Holdridge nemlilik bölgelerinin günümüz ve SBM'deki alanları.

ERA-Interim verilerine göre günümüze, $751 \mathrm{~km}^{2}$ alan kaplayan yarı doygun, yüksek doygun ve tam doygun sahalar, sadece Ağrı Dağı zirvesi ve yakın çevresi ile Doğu Karadeniz Dağlarının zirve çevrelerinde yer almakta, buzul ve kar örtüsü ile kaplı bulunmaktadır. CCSM4 model verilerine göre bu sahalar, SBM'de 6 bin km² ${ }^{2}$ yi geçmekte, günümüzde görülen alanların çevreleri ile Torosların, Munzur Dağlarının ve Uludağ’ın yüksek kesimlerinde görülmektedir.

\subsubsection{SBM'de Türkiye'deki Biyomlar}

HEB sınıflandırmasına göre günümüzde Türkiye'de belirlenen çöl çalılığı ve dikenli çalılık alanları CCSM4 iklim modeli verilerine göre SBM'de bulunmamakta (Şekil 12, Şekil 13), bunların yerlerinde başka biyomlar yer almaktadır (Şekil 12). Dikenli stepler, stepler ve kurak orman alanları SBM'de günümüze göre daha dar, nemli, sslak ve yağmur ormanları, sslak ve yağmurlu tundralar ile soğuk çöller ve buzul sahaları ise daha geniş alan kaplamaktadır (Şekil 13).

Günümüzde Türkiye'de yer almayan kurak çalılık alanı, SBM'de sadece Eleşkirt Ovasında 1 $\mathrm{km}^{2}$ 'lik bir sahada belirlenmiştir. Dikenli step alanları (bozkır) ise, günümüzde 66 bin $\mathrm{km}^{2}$ alan kaplamakta ve İç, Doğu ve Güneydoğu Anadolu Bölgesinde yayılmaktayken, SBM'de oldukça daralmakta $884 \mathrm{~km}^{2}$ alanda görülmekte sadece Güneydoğu Anadolu Bölgesinin güneyinde ve Mut Havzası'nda karşımıza çıkmaktadır.

Step sahaları, günümüzde İç ve Doğu Anadolu Bölgesinin yüksek platolarında görülmekte (Şekil 12a), Türkiye'nin yaklaşık dörtte birini kaplamaktadır (Şekil 13). SBM'de alanı daralan steplerin görüldüğü sahalar günümüzden farkl111k göstermektedir. Bu biyom SBM'de daha alçak yerlerde, 
Güneydoğu ve İç Anadolu Bölgesinin alçak plato ve ovalarında, Doğu Anadolu Bölgesinin depresyon tabanlarında, Orta Karadeniz Bölümü ve Denizli çevresindeki ovalarda hâkim durumdadır. Bu sahalardan İç ve Doğu Anadolu Bölgesindekiler günümüzde dikenli step, Güneydoğu Anadolu Bölgesindekiler ise dikenli çalılık özelliği göstermektedir.
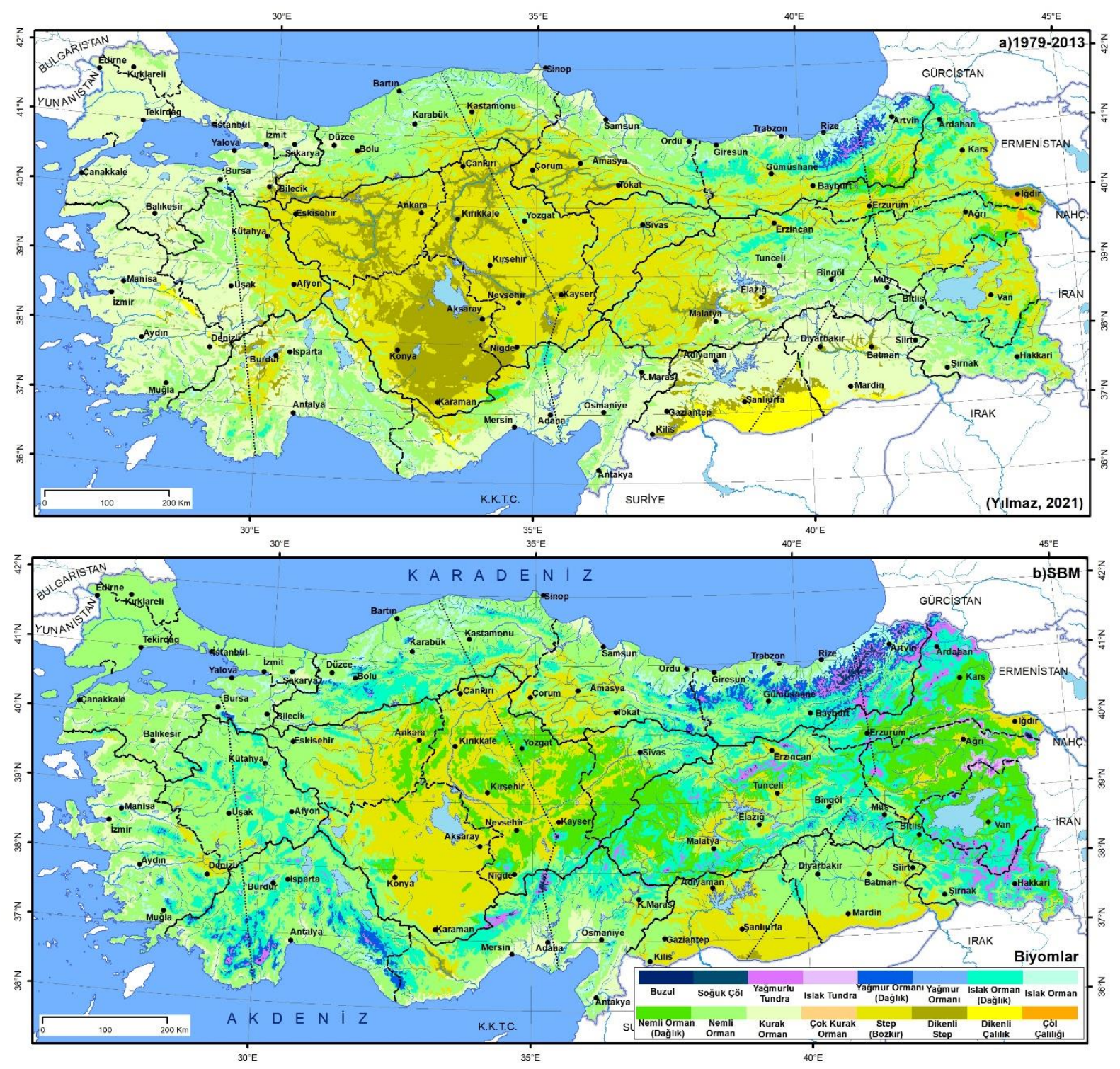

Şekil 12.Türkiye'de günümüz ve SBM'de biyom dağılışları ve profil hatları.

Günümüz koşullarında Doğu ve Güneydoğu Bölgeleri ile Akdeniz, Ege ve Marmara Bölgesinde geniş alan kaplayan kurak orman biyomu (Yılmaz, 2021), CCSM4 model verilerine göre SBM'de Akdeniz, Ege, Marmara ve Karadeniz kıyı ovaları ile bu ovaları oluşturan akarsu vadilerinde ve bu vadiler boyunca gelişmiş alçak ovalarda görülmektedir (Şekil 12). Bu biyom günümüzde 232 bin km² alan kaplarken, SBM'de bu alanın beşte biri kadar sahaya sıkışmış ve alanı daralmıştır (Şekil 13).

Nemli orman biyomu günümüzde Karadeniz Bölgesinde deniz seviyesinden başlarken, diğer bölgelerde yüksek dağlık alanlarda görülmektedir (Yılmaz, 2021). SBM'de bu biyom alanı genişlemiş, 320 bin km² $^{2}$ alan ile Türkiye'nin yarısına yakınını kaplamıştır. Bu biyom açısından dikkati çeken bir 
diğer husus, CCSM4 model verilerine göre SBM'de Dicle Bölümü’nde de görülmesidir. Dağlık nemli orman biyomu ise günümüzde Doğu Anadolu ve Akdeniz Bölgesi gibi bölgelerde, dağların çok yüksek kısımlarında karşımıza çıkarken, SBM'de Yukarı Murat, Van Gölü, Erzurum-Kars Bölümleri ile Uzunyayla Platosu ve İç Anadolu Bölgesinin çok yüksek platolarında geniş alanlar kaplamaktadır.

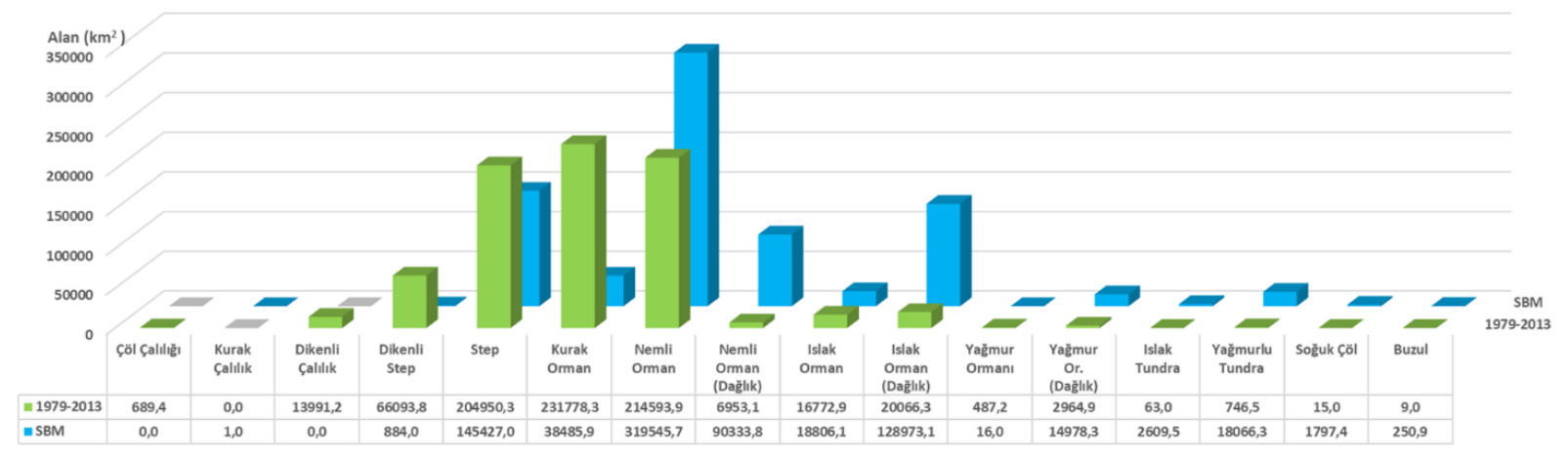

Şekil 13. Türkiye'de günümüz ve SBM'de biyom alanları.

ERA-Interim verilerine göre günümüzde 17 bin $\mathrm{km}^{2}$ alan kaplayan 1slak orman biyomunun SBM'deki alanı 19 bin km²'yi geçmekte (Şekil 13), büyük bir bölümü Doğu Karadeniz kıyılarında yer almaktadır (Şekil 12). 13 bin km²' den geniş alan kaplayan dağlık ıslak orman biyomunun da SBM'deki alanı artmış, günümüze göre 6 kat geniş alan kaplamıştır.

Günümüz ortalamalarına göre Uludağ ve Doğu Karadeniz Dağlarının yüksek kesimlerinde yaklaşık $3500 \mathrm{~km}^{2}$ alan kaplayan yağmur ve dağlık yağmur ormanı biyomları (Şekil 12, Şekil 13), CCSM4 verilerine göre SBM'de tüm coğrafi bölgelerde görülmekte ve 15 bin km² civarında alan kaplamaktadır (Şekil 12). Burada dikkat çeken husus, yağmur ormanlarının SBM'de daha dar alan kaplarken, dağlı yağmur ormanlarının genişlemesidir. $\mathrm{Bu}$ durum sıcaklık azalmasından kaynaklanmakta, bu azalmaya bağlı olarak evapotranspirasyon oranları düşmekte ve yağış miktarı aynı olsa da evapotranspirasyon-yağış oranı düşmekte ve HEB üçgenindeki yeri değişerek daha serin bir özellik göstermektedir.

Islak ve yağmurlu tundra sahaları günümüz ortalamalarına göre Türkiye'de $810 \mathrm{~km}^{2}$ alan kaplamakta ve büyük kısmı Doğu Karadeniz Dağları'nın yüksek kısımlarında yer almaktadır. SBM'de her iki biyom da daha geniş sahalarda görülmekte, tüm bölgelerde karşımıza çıkmakta ve 19 bin km² alana yaklaşmaktadır. Güzümüzde sadece Ağrı Dağı zirvesi ve çevresinde $15 \mathrm{~km}^{2}$ alan kaplayan soğuk çöl ve $9 \mathrm{~km}^{2}$ alan kaplayan buzul sahaları, SBM'de genişlemekte, toplam alanları 2000 km²'yi aşmaktadır.

CCSM4 iklim modeli ile SBM için oluşturulan model verilerine göre yukarıda anlatılan biyom dağılışı, Türkiye'nin doğusundan, ortasından ve batısından alınan genel hatlarıyla güney-kuzey doğrultulu 3 hatta, topografik profil üzerinde incelenmiş ve yükselti açısından farklılıklar belirlenmiştir. Bu hatlardan batı hattı, Finike ile Mudanya arasında alınmış (Şekil 12), en güneyde, Akdeniz kıyılarında hem günümüzde hem SBM'de kurak orman biyomunun hâkim olduğu, kıyıdan Alaca Dağ'a çıkışta ise günümüzdeki biyomların SBM'de daha alçaklarda görüldüğü, dağın zirve çevresinde yağmur ormanı, zirvesinde ise yağmurlu tundralar olduğu belirlenmiştir (Şekil 14). Bey ve Ziyaret Dağlarının 
zirvelerinde nemli ormanlarının yerinde SBM'de yağmur ormanları, Teke Platosundaki polyelerde günümüzde hâkim olan kurak orman ve steplerin yerlerinde alçak polyelerde nemli, yüksek polyelerde ise dağlık sslak orman biyomu hâkim durumdadır. Tefenni Ovası ile Acıgöl çevresindeki dikenli stepler ve kurak ormanların yerinde SBM'de nemli orman biyomu bulunmaktadır. Günümüzde bu sahadaki Beşparmak Dağı gibi yüksek kesimlerde hâkim olan nemli ormanlar model verilerine göre SBM'de dağlık 1slak orman özelliğindedir.

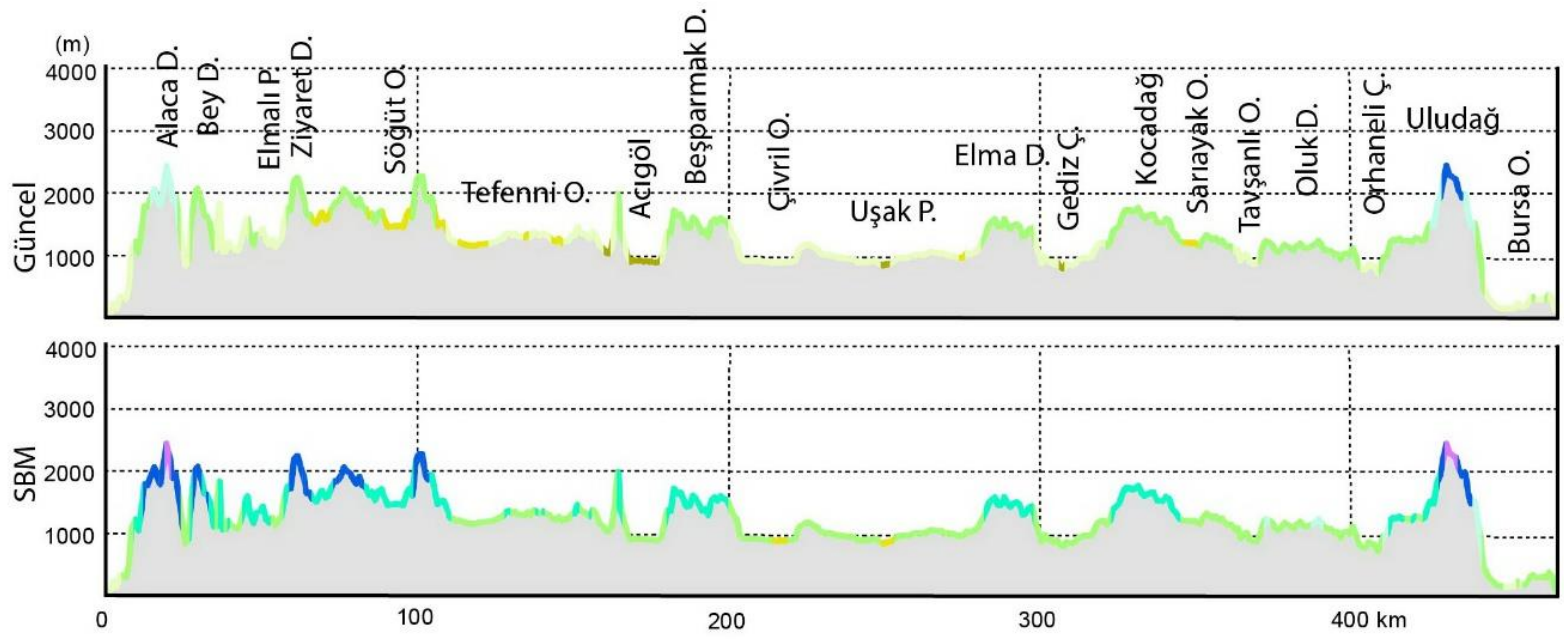

Şekil 14. Finike-Mudanya arası hatta güncel ve SBM'deki biyom dağılışı (Renkler Şekil 12 ile aynıdır).

Batıdaki hat boyunca devam edildiğinde, günümüz ortalamalarına göre Çivril Ovası ve Uşak Platosunda hâkim olan kurak ormanlar yerinde SBM'de nemli ormanlar hâkimken, bu sahadaki vadi tabanlarında dikenli çalılık biyomu yer almaktadır. Elma Dağındaki nemli orman, SBM'de dağlık ıslak orman özelliği göstermektedir. Gediz vadisinde günümüzde dikenli step hakimken SBM'de dikenli çalılık, vadi yamaçlarında ise günümüzde kurak SBM'de nemli orman biyomu bulunmaktadır. Kocadăg ve Oluk Dağı arasındaki sahada günümüzde yüksek kısımlarda hâkim olan nemli orman yerine SBM'de 1slak orman bulurken, daha yükseltisi düşük platolarda hem günümüz hem de SBM'de nemli orman biyomu hakimdir. Uludağ zirvesi ve çevresinde SBM'de yağmurlu tundralar hâkim görünmekte, daha alçaklarda görülen yağmur ormanları kuzeyde daha alçaklara inmekte, bakı etkisi görülmektedir (Şekil 14).

Türkiye'nin ortasından alınan hat, kabaca Çukurova'dan başlayıp Aladağlar ve Erciyes Dağı'ndan geçerek İnebolu'ya ulaşmaktadır (Şekil 12). Bu hat incelendiğinde, günümüzde Çukurova'da kurak orman, Kale Dağı ve Aladağ'ın yamaçlarında nemli orman, Aladağlarda 1slak ve dağlık ıslak orman biyomu hakimken, SBM'de, kurak ormanın Çukurova'nın alçak kısımlarında kalabildiği, ıslak orman biyomlarının Aladağların yamaçlarına indiği, zirve çevresinde ise buzul ve tundra alanlarının hâkim olduğu görülmektedir (Şekil 15). Develi Ovası'nda günümüzde dikenli step, SBM'de ise step sahası hakimken, Erciyes Dağı zirvesinde günümüzdeki ıslak tundra sahaları SBM'de yağmurlu tundra ve buzul sahaları olarak belirlenmiştir. 


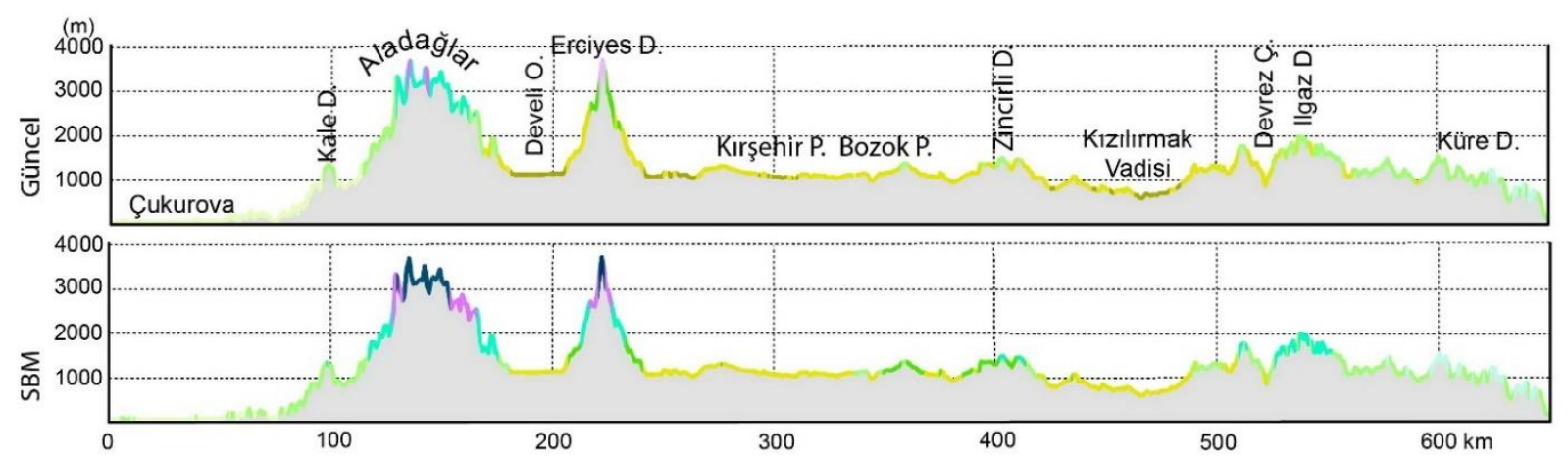

Şekil 15. Çukurova-İnebolu arası hatta, güncel ve SBM'deki biyom dağılışı (Renkler Şekil 12 ile aynıdır).

Kırşehir ve Bozok Platolarının alçak kesimlerinde günümüzde görülen dikenli stepler SBM'de step, plato üzerindeki yüksek sahalarda ise nemli ormanlar hakimdir. Zincirli Dağı çevresinde dağlık nemli ormanlar da görülmekte, Kızılırmak Vadisi'nde ve Devrez Oluğunda da stepler yer almaktadır. Günümüzde Ilgaz Dağında görülen nemli ormanların yerinde SBM'de sslak ve dağlık 1slak orman biyomu bulunmaktadır. Kastamonu çevresinde ve Küre Dağlarından Karadeniz kıyılarına kadar olan kısmında günümüzde hâkim olan ıslak orman biyomu SBM'de de bulunmaktadır. Bu saha hem günümüzde hem de SBM'de HEB sınıflamasına göre aynı biyoma sahiptir ve bu özelliğiyle Kütahya çevresine (Oluk Dağı-Kocadağ arası) benzemektedir.

Doğudan alınan topografik profil, Harran Ovası'ndan başlayıp Bingöl Dağı'na ulaştıktan sonra Doğu Karadeniz kıyılarına doğru uzanmaktadır (Şekil 12). Bu hatta hem Harran Ovası hem de Viranşehir Platosunda günümüzde hâkim olan dikenli çalılık biyomu yerine SBM'de ovada dikenli step, plato alanında ise step biyomu belirlenmiştir (Şekil 16). Günümüzde Karacadağ zirvesi çevresinde görülen nemli orman biyomu, SBM'de yamaçlara inmekte, zirvede dağlık 1slak orman biyomu hâkim olmaktadır. Bu biyomun günümüzde Bingöl Dağı'nda görülürken SBM'de Karacadağ'da görülmesi, enlemsel olarak 2 dereceye yakın bir değişim olduğunu göstermektedir. Hat boyunca ilerlendiğinde, Diyarbakır Havzası'nda günümüzde kurak, SBM'de nemli orman biyomunun görüldüğü, Güneydoğu Toroslarda görülen nemli ve 1slak ormanlar yerine SBM'de dağlık sslak ve yağmur ormanlarının hâkim olduğu belirlenmiştir. Bingöl Dă̆ı'na kadar, kurak ormanların yerinde nemli, nemli ormanlar yerinde ise 1slak ve dağlık 1slak ormanlar, Bingöl Dağı zirvesinde ise SBM'de yağmurlu tundralar hâkim durumdadır. Bingöl Dağı, günümüzde paleobuzul şekillerinin görüldüğü (Tonbul, 1997) bir sahadır ve buna bağlı olarak bu hat çevresindeki yağmurlu tundralarda SBM'de buzul süreçlerinin hâkim olduğu anlaşılmaktadır. 

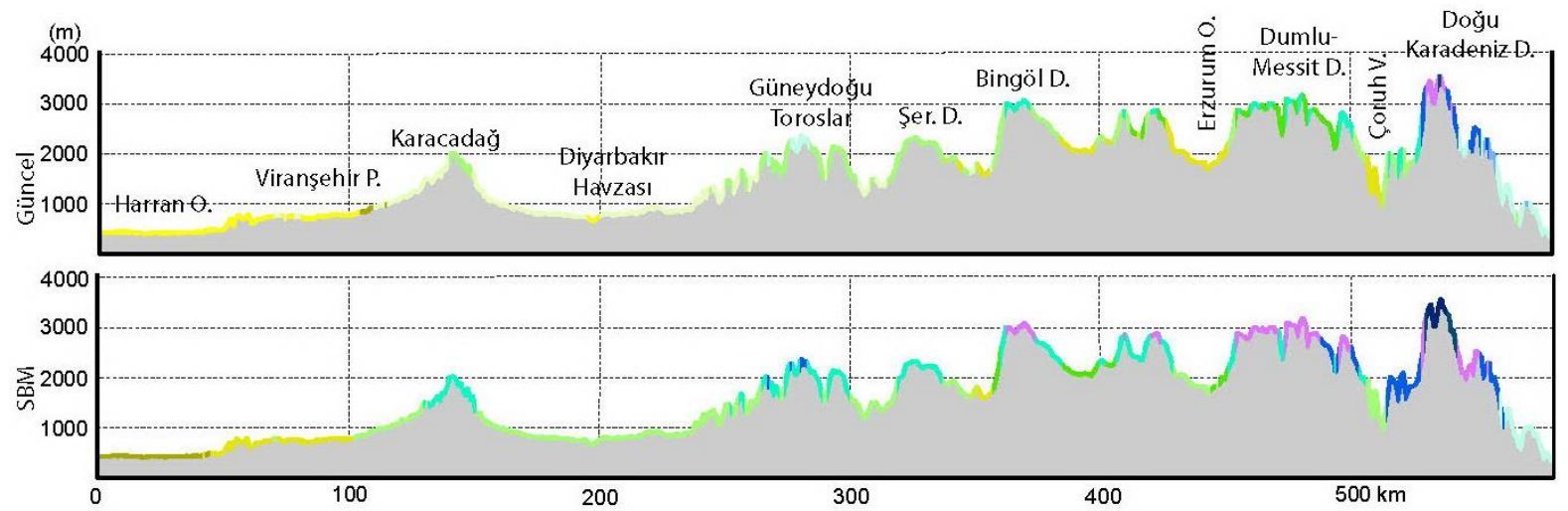

Şekil 16. Harran-Karadeniz arası hatta güncel ve SBM'deki biyom dağılışı (Renkler Şekil 12 ile aynıdır).

ERA-Interim verilerine göre Bingöl Dağı kuzeyinde, Tekman Oluğunda kurak orman ve step, Palandöken Dağları çevresinde ise nemli ve dağlık ıslak orman hakimken, CCSM4 verilerine göre SBM'de olukta nemli orman, yamaçlarda dağlık ıslak orman, Palandöken Dağlarında ise yağmurlu tundra biyomu saptamış, Erzurum Ovasında ise step yerine nemli orman biyomu belirlenmiştir. Günümüzde yağmur ormanı ve ıslak ormanların hâkim olduğu Dumlu ve Mescit dağlık alanında SBM'de yağmurlu tundralar görülmektedir. Bu sahalar paleobuzul sahalarıdır (Atalay, 1984; Yalçınlar, 1951) ve günümüzde periglasyal süreçler hakimdir. Günümüz ortalamalarına göre Çoruh Vadisinde asimetrik bir biyom dağılışı görülmekte, kuzeye bakan yamaçlarda step, güneye bakan yamaçlarda ise nemli orman bulunmaktadır. SBM'de asimetri devam etmekte, nemlilik artmakta, güneye bakan yamaçlarda dağlık yağmur ormanı bulunmaktadır. Doğu Karadeniz Dağlarında günümüz şartlarında hâkim olan tundra sahaları SBM'de soğuk çöl ve buzul özelliği göstermekte, Karadeniz kıyılarında ise günümüzde hâkim olan ıslak ormanlar SBM'de de görülmekte, daha alçaklarda karşımıza çıkmakta, bu kıyılar hem günümüz hem de SBM'de aynı biyomların görüldüğü üçüncü bölge özelliği göstermektedir.

\subsubsection{SBM’de Türkiye'deki Tümleşik HEB Sinıfları}

Günümüzde Türkiye'de 63 tümleşik HEB sınıfı bulunmaktadır. Bu sınıf sayısı CCSM4 model verilerine göre SBM'de değişmiş, bazı sınıfların alanı darken, bazılarının geniş olduğu, bazı sınıfların SBM'de bulunmadığı bazı sınıfların ise SBM'de varken günümüz iklim şartlarında görülmediği belirlenmiştir. Analizler sonucunda SBM'de 58 farklı tümleşik HEB sınıfi belirlenmiş ve iklim çeşitliliğinin günümüze göre düşük olduğu görülmüştür (Şekil 17).

SBM'de belirlenen, yarıalpin-yarı nemli-kurak çalılık (50703), alpin-çok doygun-soğuk çöl (60219), yarı doygun-soğuk çöl (60319), karl1-tam doygun-soğuk çöl (70119), çok doygun-yağmurlu tundra (70218), yarı doygun-yağmurlu tundra (70318), yarı doygun-soğuk çöl (70319) ve aşırı nemli yağmurlu tundra (70418) alanları günümüzde Türkiye'de bulunmamaktadır (Şekil 17, Şekil 18). 

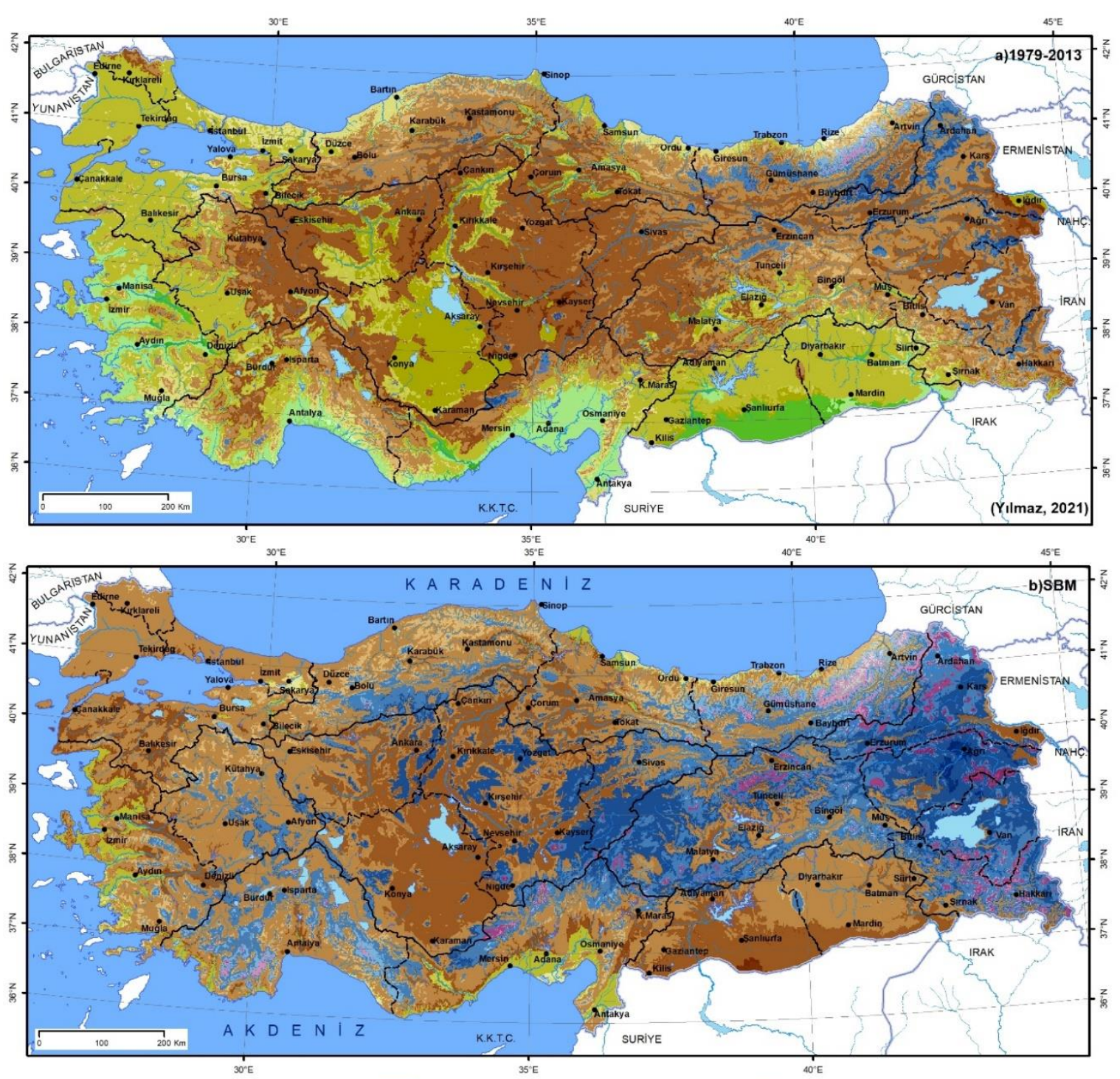

Alçakirtifa Nemli Nemli Orman

20708 Alçakirtifa Yarı Nemli Kurak Orman

20709 Alçakirtifa Yari Nemli Nemli Orman

20804 Alçakirtifa Yarı Kurak Dikenli Çalılıı

20808 Alçakirtifa Yarı Kurak Kurak Orman

30509 Dagönu Çok Nemli Nemli Orman

30511 Daăönü Cok Nemli Islak Orma

30608 Dağöna Nemli Kurak Orman

30609 Dagona Nemil Nemli Orma

30705 Dağoona Yarı Nemli Dikenli Step

30706 Dagöna Yarı Nemli Step

30708 Dağönü Yarı Nemli Kurak Orman

0802 Dağonno Yarı Kurak Cóı Caliıı̆ı

30805 Dagona Yarı Kurak Dikenll Step

40411 Dağıık Așırı Nemli ıslak Orman

40413 Dağlık Aşııı Nemli Yağmur Orman

40414 Dağık Așııı Nemli Yagmur Or. (Dağık)

40509 Dağlik Cok Nemli Nemli Orma

40511 Dağlik Cok Nemli Islak Orman

40512 Dağık Cok Nemli Islak Orman (Daglık)

40513 Dağık Çok Nemli Yağmur Ormanı

40606 Daglık Nemli Step

40609 Dağlık Nemli Nemli Orman

40610 Dağlık Nemli Nemli Orman (Dağıık)

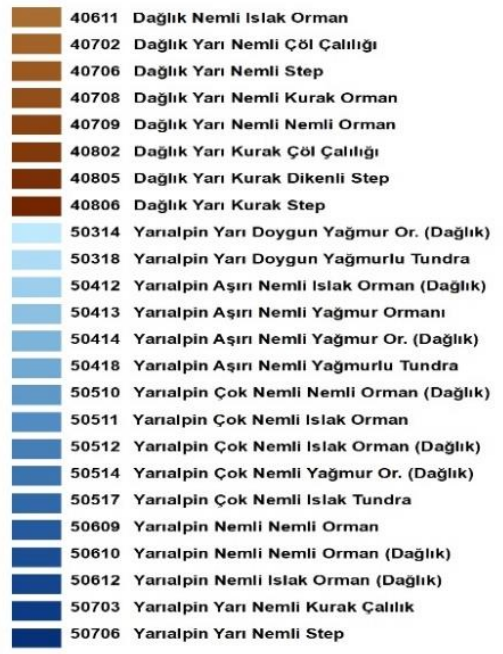

50710 Yarıal pin Yarı Nemli Nemli Orman (Dağli 60218 Alpin Çok Doygun Yağmurlu Tundra 60219 Alpin Çok Doygun Soğuk Çoł 60314 Alpin Yarı Doygun Yağmur Or. (Dağlık) 60318 Alpin Yarı Doygun Yağmurlu Tundra 60319 Alpin Yan Doygun Soguk Cö 60414 Alpin Așırı Nemli Yağmur Or. (Dağık) 60417 Alpin Așırı Nemli ıslak Tundra 60417 Alpin Așırı Nemli Islak Tundra
60418 Alpin Așırı Nemli Yağmurlu Tundra 60512 Alpin Çok Nemli Islak Orman (Dağık) 60517 Alpin Çok Nemlil Islak Tundra

60518 Alpin Cok Nemli Yağmurlu Tundra 60610 Alpin Nemli Nemli Orman (Dağlık) 70119 Karı Tam Doygun Soğuk çoı 70120 Karlı Tam Doygun Buzul 70218 Karı Çok Doygun Yağmurlu Tundra 70219 Karı Çok Doygun Soğuk Çöı 70220 Karı Cok Doygun Buzul 70318 Karl Yarı Doygun Yağmurlu Tundra 0319 Karı Yarı Doygun Soguk ço 70320 Karlı Yarı Doygun Buzul 70418 Karlı Așırı Nemli Yağmurlu Tundra 70419 Karlı Așırı Nemli Soğuk Çŏ

Şekil 17. Günümüz ve SBM'deki tümleşik HEB sınıfları. 
SBM'deki alanı günümüze göre dar olan sınıflar içerisinde dağönü-nemli-kurak ormanlar (30608), nemli-nemli ormanlar (30609), yarı nemli-dikenli stepler (30705), stepler (30706), kurak ormanlar (30708), yarı kurak-dikenli stepler (30805), dağlık-aşırı nemli-yağmur ormanları (40413), nemli-1slak ormanlar (40611), dağlık-yarı nemli-stepler (40706), kurak ormanlar (40708), nemli ormanlar (40709), yarı kurak-dikenli stepler (40805), yarı kurak-stepler (40806), yarıalpin-yarı doygundağlık yağmur ormanları (50314), alpin-yarı doygun-dağlı yağmur ormanları (60314) ve karl1-yarı doygun-buzul (70320) sahaları bulunmaktadır (Şekil 17, Şekil 18).

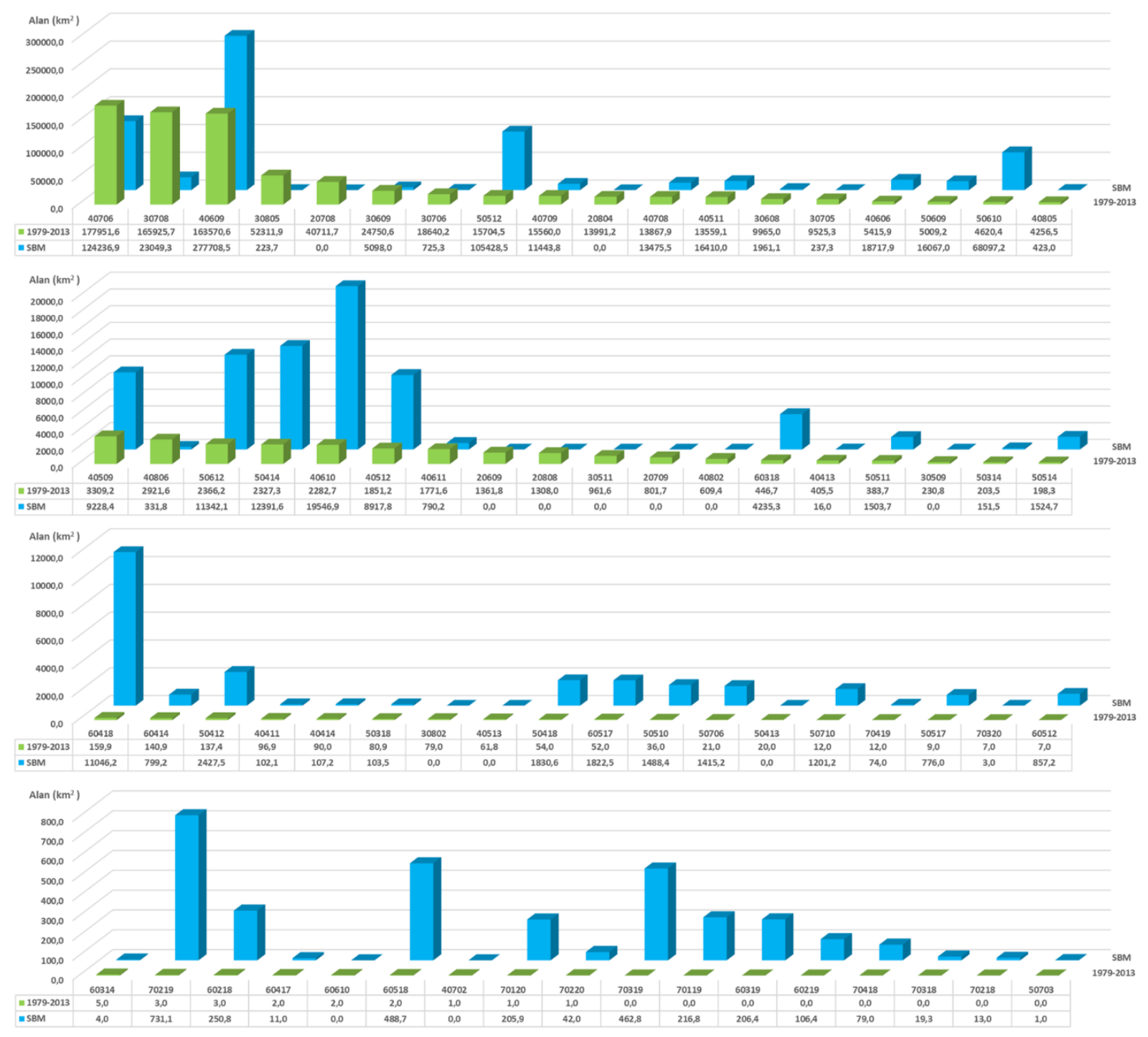

Şekil 18. Tümleşik HEB sınıflarının günümüz ve SBM'deki alanları (Kodlar için Şekil 17'ye bakınız).

Günümüzde Türkiye'de yer alan alçak irtifa-nemli-nemli ormanlar (20609), yarı nemli-kurak ormanlar (20708), nemli ormanlar (20709), yarı kurak-dikenli çalılıklar (20804), kurak ormanlar (20808), dağönü-çok nemli-nemli ormanlar (30509), çok nemli-1slak ormanlar (30511), yarı kurak-çöl çalılıları (30802), dağlık-çok nemli-yağmur ormanları (40513), yarı nemli-çöl çalılıkları (40702), yarı kurak-çöl çalılıkları (40802), yarıalpin-aşırı nemli-yağmur ormanı (50413) ve nemli- dağlık nemli ormanlar (60610) SBM'de belirlenememiştir (Şekil 17, Şekil 18). 
Günümüzdekine göre SBM'de alanı daha geniş olan sınıflar içerisinde, dağlık-aşırı nemli-ıslak ormanlar (40411), dağl1k yağmur ormanları (40414), çok nemli-nemli ormanlar (40509), sslak ormanlar (40511), dağl1k 1slak ormanlar (40512), nemli-stepler (40606), nemli ormanlar (40609), dağlık nemli ormanlar (40610), yarıalpin-yarı doygun-yağmurlu tundralar (50318), aşırı nemli-dağlık 1slak ormanlar (50412), aşırı nemli-dağlık yağmur ormanları (50414), yağmurlu tundralar (50418), çok nemli-nemlidağlık ormanlar (50510), 1slak ormanlar (50511), dağlık 1slak ormanlar (50512), dağlık yağmur ormanları (50514), ıslak tundralar (50517), nemli-nemli ormanlar (50609), dağlık nemli ormanlar (50610), dağlık ıslak ormanlar (50612), yarı nemli-stepler (50706), dağlı nemli ormanlar (50710), alpin-çok doygun-yağmurlu tundralar (60218), yarı doygun-yağmurlu tundralar (60318), aşırı nemlidağlık yağmur ormanları (60414), ıslak tundralar (60417), yağmurlu tundralar (60418), çok nemlidağlık ıslak ormanlar (60512), 1slak tundralar (60517), yağmurlu tundralar (60518), karl1-tam doygunbuzullar (70120), çok doygun-soğuk çöller (70219), buzullar (70220) ve aşırı nemli-soğuk çöller (70419) yer almaktadır (Şekil 17, Şekil 18).

\section{Tartışma}

CCSM4 model verilerine göre, SBM için belirlenen aylık ortalama sıcaklıkların günümüz ortalamalarından farkları, Türkiye'nin kuzeyine doğru düşmekte, Güneydoğu Anadolu Bölgesinde ise $10^{\circ} \mathrm{C}$ '1 aşmaktadır. Karadeniz çevresinde nemlilik şartlarının yüksek olduğu göz önüne alındığında, farkların nemlilik şartlarına bağlı olarak değiştiği, bağıl nemin yüksek olduğu sahalarda sıcaklık farkının diğer sahalara göre daha düşük olduğu anlaş1lmaktadır. Benzer durum, geleceği öngören iklim modeli sonuçlarında da görülmekte, nemliliğin düşük olduğu Güneydoğu Anadolu Bölgesinde gelecekteki sıcaklık artışlarının daha yüksek olacağı tahmin edilmektedir (Akçakaya vd., 2015; Önol ve Semazzi, 2009). Yine Türkiye genelinde, yıl içindeki sıcaklık farklarının SBM'de kışın yüksekken, yaz aylarında düştüğü görülmektedir. Günümüzde Türkiye genelinde kış aylarındaki bağıl nem yüksek, yaz aylarında, yağışın azaldığı bölgelerde düşüktür. Sicaklığın arttığı dönemlerde bağıl nem azalmakta, bu duruma ortamdaki su yoksunluğu neden olmaktadır. Buna rağmen, günümüzde Karadeniz çevresinde, bağıl nem değerleri kışın nispeten düşük, yaz aylarında yüksektir. Bu bölgede her mevsimde mevcut olan su, yaz aylarında artan enerjiye bağlı olarak buharlaşma ve bağıl nemi artırmaktadır. Günümüze göre SBM'deki sıcaklık farklarının kışın yüksek olması, bu dönemde alınan yağışların sıcaklığın düşük olması nedeniyle yeterince buharlaşamaması ve enerji artışının yaz aylarına kayması-denk gelmesi, bağıl nem değerlerinin yaz aylarında yükselmesi ile ilişkili olmalı, yaz mevsimdeki sıcaklık farkı düşüklüğü bu durumdan kaynaklanmalıdır.

SBM'de, teorik olarak en soğuk ve en sıcak dönemlerin günümüze göre değişmesi beklenmekte, yalpa hareketine (precession) bağlı olarak gün dönümleri ve ekinoks zamanlarının kayacağı öngörülmektedir. Bu harekete bağlı olarak sıcak ve soğuk aylar ancak 26000 yılda çakışmalı (Moebs, Ling ve Sanny, 2016), diğer zamanlarda değişmelidir. Bununla birlikte, model verilerinde en sıcak ve en soğuk aylarda belirgin bir değişim görülmemiş, dar alanlı (en soğuk ayın Trakya'da aralık ayına denk gelmesi) farklılıklar belirlenmiştir. SBM'de yalpa hareketi parametresi (YHP) farklılık göstermekte (Şekil 19), en sıcak ve en soğuk dönemlerin yalpa hareketine bağlı olarak değiştiği, bunun Türkiye'de küçük bir sahaya yansıdığı anlaşılmaktadır. Değişimin az olması, yalpa hareketi döngüsünün günümüze 
benzer durumunun (döngünün tamamlanması) zamansal olarak SBM'ye yakın olmasından kaynaklandığı anlaşılmaktadır. Bu duruma, kullanılan model kabiliyetinin bu hareket parametresini yeteri kadar yansıtmamasının da rolü olabilir.

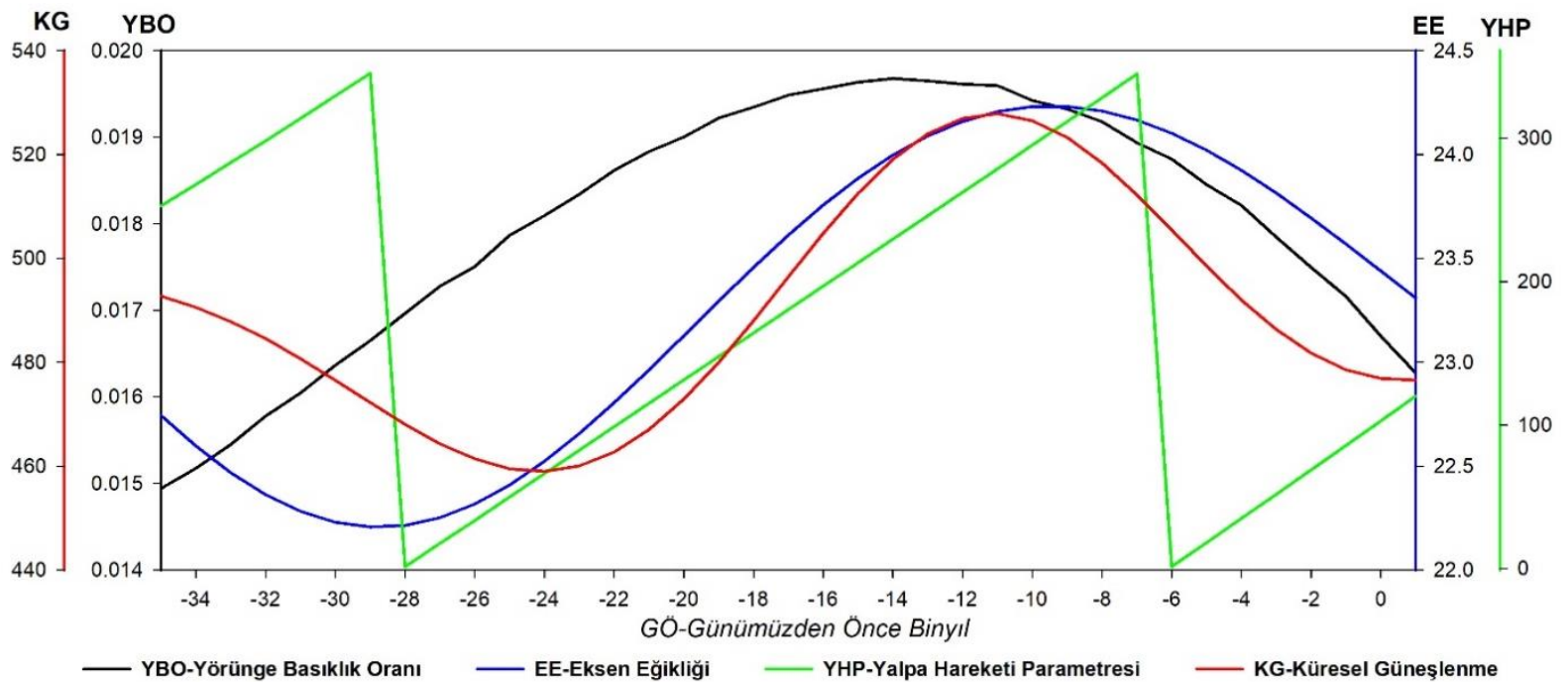

Şekil 19. Son 35 bin ve gelecek bin yılda Milankoviç Döngülerinin değişimi (Laskar vd., 2011). Eksen eğikliği (EE) derece,

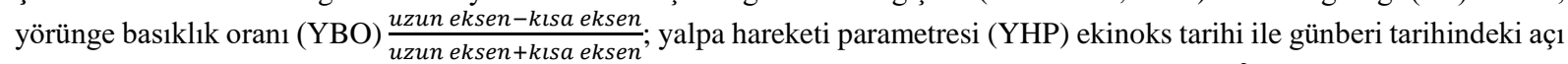
fark1, küresel güneşlenme $(\mathrm{KG}) 65^{\circ} \mathrm{K}$ enleminde yaz gündönümündeki güneşlenme miktarı, $\mathrm{W} / \mathrm{m}^{2}$ 'dir. Her değişken, kendi rengindeki düşey ölçek ile gösterilmiştir.

Geometride dışmerkezlilik, elipsin odak noktalarıyla elips üzerindeki herhangi bir nokta arasındaki uzaklık ile odak noktasının elipsin doğrultmanına olan uzaklığa oranı olarak tanımlanmakta, Laskar vd. (2011) tarafından yapılan hesaplarda ise elipsin eksen uzunlukları arasındaki farkın elipsin eksenleri toplamına oranı olarak ifade edilmiş, bir tür yörünge basıklık oranı (YBO) olarak verilmiştir. Bu durumda elipsin şekli daireye doğru benzediğinde oran 0'a yaklaşmakta, değer arttığında ise kısa ve uzun eksen uzunluğu arasındaki fark artmaktadır. Günümüzde bu oran 0.016702 olarak belirlenirken, SBM'deki 0.019223'tür (Şekil 19). SBM'de basıklık oranının yüksek olması, güneşe en yakın konumun günümüze göre daha yakın, en uzak konum ise günümüze göre daha uzak olmasına neden olmaktadır. Bunun da mevsimsel değişkenliği artıracağı anlaşılmaktadır.
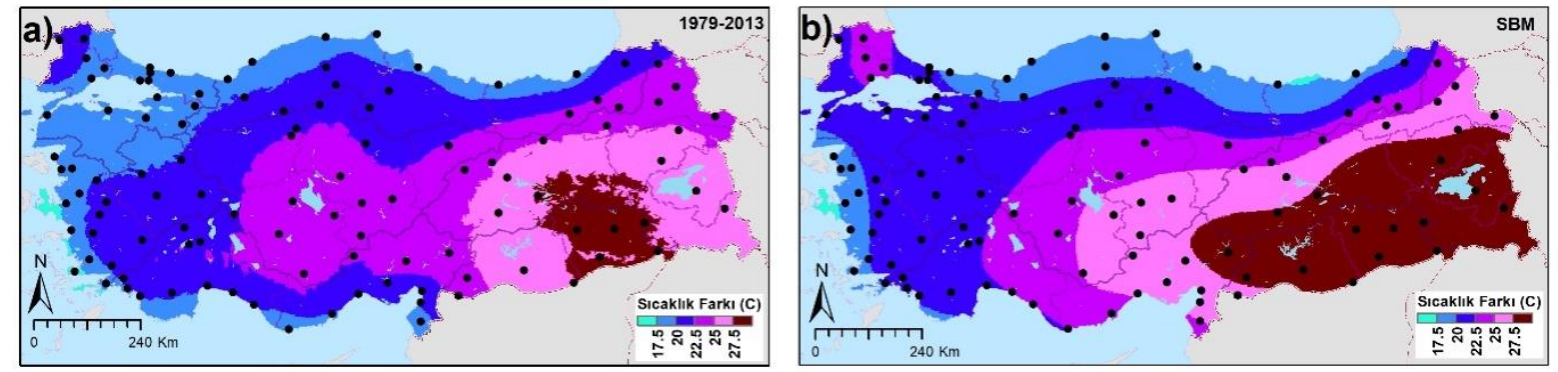

Şekil 20. Günümüz ve SBM'deki yıllık sıcaklık genlikleri (En yüksek aylık ortalama sıcaklık ile en düşük aylık ortalama sicaklık fark1).

Eksen eğikliğinin (EE) artması, yıl içindeki iklimsel değişkenliği artırırken, azalması mevsim değişkenliği azaltmakta, eğikliğin ortadan kalkması ise mevsimsel farklılıkların ortadan kalkmasına neden olmaktadır. SBM'de eksen eğikliğinin $23^{\text {s }}$ den daha düşük olması (Şekil 19) ekinoks 
dönemlerinde güneş 1şıllarının kışın daha yüksek, yazın daha düşük gelmesine neden olmuş, günümüze göre kış ve yaz mevsimleri arasındaki enerji bütçesi farklılığını düşürmüş olmalıdır. Bununla birlikte, bu döngü tek başına etkili olmadığından, CCSM4 verilerinde Türkiye'deki yıl içindeki sıcaklık farklılığı SBM'de günümüzden daha yüksek çıkmış, (Şekil 20) Türkiye'nin güneydoğusuna doğru artmıştır.

SBM'de Türkiye'de yağışları günümüze göre değişmiş dağlık alanlar daha yüksek yağışlar alırken, kıyılar ve alçak sahalar daha düşük yağışlar almış, Karadeniz ve Marmara birer göl özelliği göstermiştir (Şekil 21, -120 eş derinlik eğrisi). Dağlık alanların yüksek yağış alması, bu dönemde düşen sıcaklıklar ve buna bağlı yoğuşma seviyesi alçalması ile ilişkili olabileceği düşünülmektedir.

SBM'de kıyılarda görülen yağış azlığı, Karadeniz ve Marmara göllerinin daralmasıyla birlikte, bu su yüzeylerinin yağış getiren hava kütlelerinin etkisini artırma-nemlendirme etkisinin düşmesiyle ilgili olabileceği gibi, bu dönemde düşük sıcaklıktaki göl sularının bu etkiyi ortadan kaldırmasıyla da ilişkili olabilir. Deniz suyu sıcaklığı ile yağışa geçebilecek su miktarı arasında pozitif bir ilişki olduğu düşünüldüğünde (Stephens, 1990), Akdeniz çevresindeki kıyılarda da yağış azalmaları belirlenmesi, bu bölgelere ulaşan siklon sıklığının azalmasıyla ilişkili olabileceği gibi yine deniz suyu sıcaklıklarının azalması ve nemlendirme etkisinin düşmesiyle de ilgili olabilir. SBM'de Türkiye'nin Akdeniz kıyılarının kışın 4, yazın 2-4 ${ }^{\circ} \mathrm{C}$ daha soğuk olduğu foraminifer analizleri sonucunda belirlenmiş (Hayes vd., 2005), Ege'de sıcaklık düşüşü $6{ }^{\circ}$ C'a kadar çıkmaktadır. SBM'de Marmara Denizi'nde (gölünde) de sıcaklıklar düşmüş, kışın 3-5, yazın ancak $10-13{ }^{\circ} \mathrm{C}$ olabilmiştir. Deniz suyu sıcaklığının azalması hem nemlendirici etkiyi azaltacak hem de hava kütlelerinin kararlılığını artıracak ve yağış azalmasına neden olabilecektir. Buna benzer bir durum günümüzde Güneyli Salınımda (Erlat, 1999) ve soğuk su akıntılarında (Türkeş, 2010: 379) karşımıza çıkmakta, su sıcaklığı düştüğünde kararlılık artmakta ve yağış miktarı düşmektedir. SBM'de dağlık alanlardaki yüksek yağışlar ise orografyanın SBM'de günümüze göre daha etkili olduğunu göstermektedir. CSM4 verilerine göre SBM'deki rejim farklılıkları, en yağışl1-kurak ve en sıcak-soğuk aylardaki mekânsal değişimlerin az olması, günümüzde Türkiye'yi etkileyen hava kütlelerin SBM'de de etkili olduğu, etki süresinde ve etki alanlarının değiştiğini göstermektedir.

CCSM4 ve ERA-Interim verileri ile belirlenen HEB sınıfları arasındaki farklar incelendiğinde, yükselti ekolojik katlarının SBM'de daha alçaklara kaydığı görülmektedir. SBM'de, yüksek dağlık alanlarda ve özellikle Doğu Anadolu Bölgesinde, yarı alpin, alpin ve karlı kat geniş alanlar kaplamaktadır. HEB yükselti ekolojik katları sıcaklık tesirini yansıtmakta (Yılmaz, 2021), dolayısıyla sıcaklı̆̆ın bir fonksiyonu özelliği göstermektedir. SBM'de sıcaklık azalması ile daha soğuk katlar genişlemiş, sıcak katlar daralmış, daha alçak sahalara sıkışmıştır. Bu durumun canlı türlerinin yaşam alanlarını da değiştireceği ve sıcaklığa duyarlı canlıların daha alçak yerlerde yaşam ortamı bulabileceği zaten bilinen bir durumdur. Doğu Anadolu Bölgesinde günümüzde var olan meşe ve sarıçam orman sahalarının SBM'de yarı alpin ve alpin kata dönüştüğü, bu sahalarda ağaç formasyonunun ortadan kalktığı görülmektedir.

SBM'de kara olan, Marmara, Karadeniz, Ege ve Akdeniz kıyıları, günümüz kıyıları için CCSM4 verilerine göre belirlenen sinıflarla ya da bu sınıflardan daha sıcak özellik gösteren komşu HEB sınıfları ile kaplı olmalıdır. 
HEB sınıflandırmasında yer alan karlı kat, buzul bütçesi için önemli bir öge olan kalıcı kar sınırını temsil etmekte, bu sınır buzul alanını yarıya bölmekte (Erinç, 2001), bu sınıra bağlı buzul alanı hesaplamaları bulunmaktadır. Bu bilgiye bağlı olarak, SBM'deki buzul alanlarının, karlı katın iki katı yani $\sim 3700 \mathrm{~km}^{2}(1847 x 2)$ olmas1 gerekmekte, Yeşilyurt (2017) tarafindan da $3800 \mathrm{~km}^{2}$ olarak hesap edilmekte, buna rağmen biyom tanımlamasındaki buzul ve soğuk çöl alanları da ayrıca buzul tanımlaması için kullanılabilmektedir (Leemans, 1990; Yılmaz, 2021). Bu tanımlamaya göre ise SBM'de Türkiye'deki buzul alanı 2042 km² (soğuk çöl; 1791 + buzul; 251) olarak hesap edilmektedir. Bu konu ile ilgili, özellikle günümüz paleobuzul sahaları önem kazanmakta, bu sahaların bölgesel alanları ile karşılaştırma yapılarak model verisinin doğruluğu-güvenilirliği değerlendirilmelidir.

CCSM4 verilerine göre SBM'de, Doğu Karadeniz Dağlarında, Ağrı, Süphan, Erciyes ve Aladağlarda (Niğde) buzul sahaları belirlenmiş (Şekil 21), bunların yanında Cilo, Mengene, İhtiyarşahap, Tendürek, Karçal, Yalnızçam, Giresun, Munzur, Bolkar Dağları, Akdağlar, Bey Dağları, Hasan Dağı, Aras Güneyi Dağları, Tahtalı, Berit, Nurhak, Keşiş ve Mescit Dağlarında ise soğuk çöl alanları oluştuğu görülmüştür. Buna rağmen, SBM'de buzul tespit edilen (Sarıkaya vd., 2011) Uludağ, Barla, Davraz, Dedegöl, Sandıras, Honaz ve Geyik Dağlarında tundra ya da dağlık yağmur ormanları belirlenmiştir. Bu sınıflar, daha önce tanımlanmamış HEB sınıfları içerisinde yer almaktadır. $\mathrm{Bu}$ sahalarda SBM'de buzul oluşmaması ya CCSM4 verilerinin yeterli doğrulukta olmaması ve daha soğuk bir ortam olması gerektiğini ya da Şekil 1'de gösterilen 1, 2,3 numaralı bölgelerin de buzul sahası olarak tanımlanması gerektiğini göstermektedir. Çünkü, 1, 2 ve 3 numaralı alanlarda yağış yüksek olsa da buharlaşma miktarı olukça düşüktür.

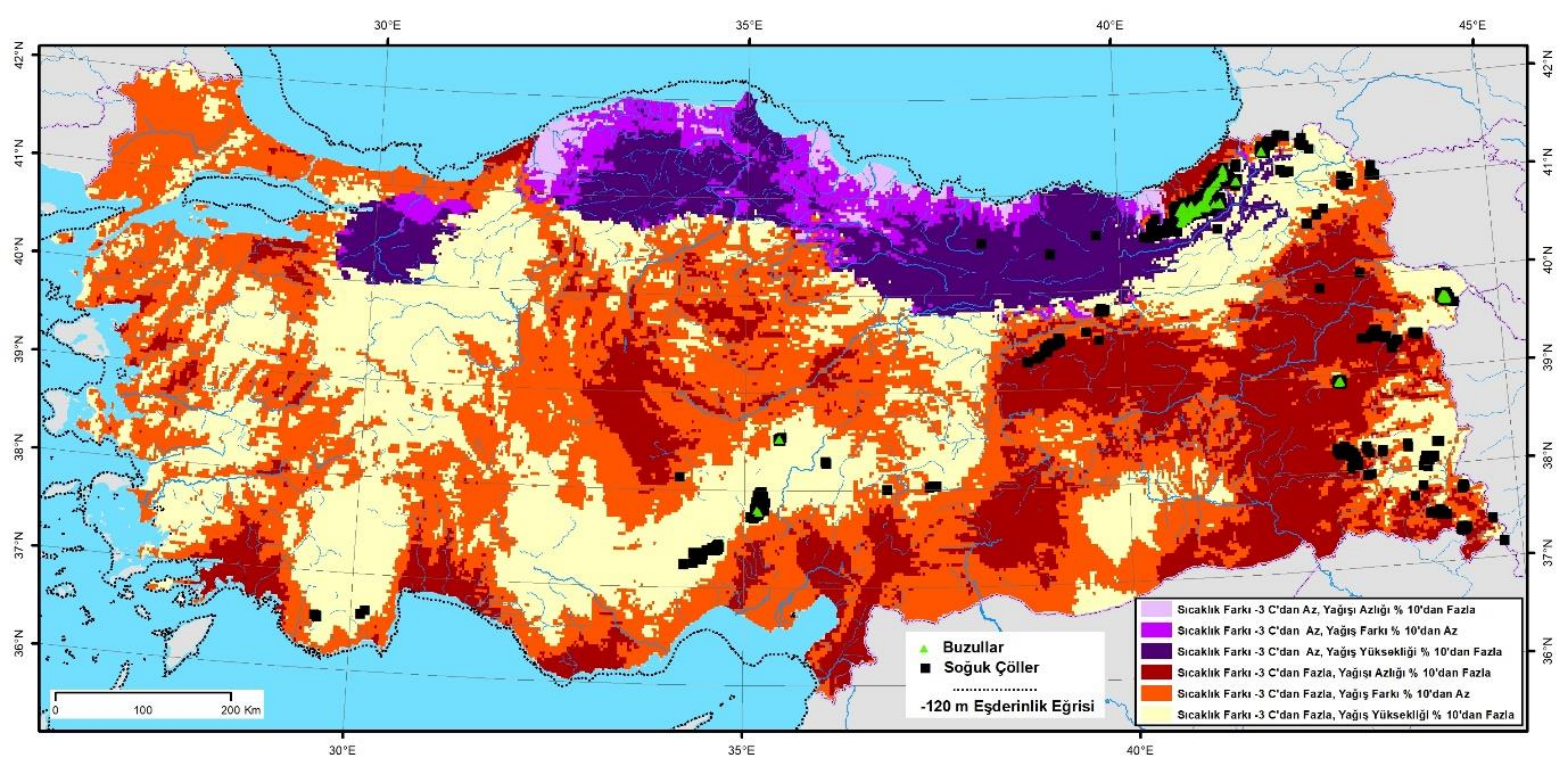

Şekil 21. CCSM4 verilerine göre SBM'de sıcaklık ve yă̆ış farklarının günümüzle karşılaştırılması, GEBCO(2020) verilerine göre SBM'deki deniz ve göl seviyeleri ve CCSM4 verilerine göre HEB sınıflarından buzul ve soğuk çöl noktaları.

Günümüz ve SBM HEB biyomları karşılaştırıldığında, Doğu ve Batı Karadeniz çevresi ile Uludağ, Sündiken, Köroğlu ve Ilgaz Dağllk sahalarında benzer biyomların olduğu görülmüştür. Bu sahalar için modellenen sıcaklık verilerinde SBM ile günümüz yıllık ortalama sıcaklık farkları $3{ }^{\circ} \mathrm{C}$ 'dan düşüktür (Şekil 21). Benzer şekilde bu sahalardaki dağlık kesimlerde yağışlar ya günümüze benzer (\% 10 fazla ya da az) özellik göstermekte ya da daha fazla düşmektedir. Bu da bu sahalar için hesaplanacak 
potansiyel evapotranspirasyon oranını azaltsa da biyomun aynı kalmasına neden olmakta, HEB sınıflarındaki biyom değişimi sınıı aşılmamaktadır.

Karadeniz'de, Samsun açıklarında yapılan bir deniz tabanı sondajında, GÖ 64-20 bin yılları arasında Karadeniz çevresinde, kurak koşulları karakterize eden step türü (grassland and dry schrublandçayır ve kurakçıl çal111k) polenlerinin yoğun olduğu görülmüş (Shumilovskikh vd., 2014), buna rağmen GÖ 28-20 by arasında nemlilik koşullarının arttığı belirlenmiştir. Bu durum, CCSM4 verileri ile kısmen örtüşmekte, SBM'de Karadeniz çevresinde daha soğuk ve daha az yağışlı bir ortam olmasına rağmen, daha nemli koşullar hâkim durumdadır.

İznik Gölü tabanında yapılan sondajdan elde dilen polen verilerine göre SBM'de göl çevresinde düşük yoğunluklu step bitki örtüsüne ait elemanlar (Artemisia ve Tubuliflorae) hâkimken, kurak ve soğuk iklim özellikleri hüküm sürmüştür (Miebach vd., 2016). CCSM4 verilerine göre bu dönemde günümüze göre daha nemli HEB biyomları belirlenmiş, soğuk şartlar hâkim olmuş, göl doğusu ile batısı ise günümüze göre farklı yağış özellikleri göstermiş, doğusunda günümüze yüksek, batısında daha düşük yağışlar belirlenmiştir.

CCSM4 verilerine göre güneybatı Anadolu'da günümüze göre nemli biyomlar hakimken, polen çalışmaları SBM'de bu bölgede (Beyşehir, Hoyran, Söğüt, Köyceğiz gölleri ve Karamık Bataklığı polen analizlerinde) Artemisia polen yoğunluğunun arttığı ve günümüze göre daha kurak bir iklimin etkili olduğu (van Zeist vd., 1975), 18-16 bin yılları arasında tüm Marmara, Ege ve Akdeniz çevresinde orman-step ya da ağaçlı stebin hakim olduğu belirtilmiştir (van Zeist ve Bottema, 1982). Buna rağmen, Sandıras Dağı ve Akdağ'da paleobuzul sahasının buzul ile kaplanabilmeleri için, SBM'de günümüze benzer 8 ile $11{ }^{\circ} \mathrm{C}$ soğuk ve günümüzün iki katı yağış alması (Sarıkaya vd., 2014; Sarıkaya vd., 2008) gerektiği belirlenmiştir. CCSM verilerine göre Sandıras Dağında dağlık yağmur ormanı, Akdağ'da ise soğuk çöl (buzul) alanları belirlenmiş, bu sahadaki sıcaklıkların hem Sandıras'ta hem de Akdağ' da $7{ }^{\circ} \mathrm{C}$ daha düşükken, yağış koşullarının Sandıras’ta \% 2 daha az, Akdağ’da \% 40-60 fazla olduğu belirlenmiştir.

SBM'de Orta ve Batı Anadolu'daki göl seviyeleri yükselmiş (Erol, 1971,1995; Kashima, 2002), Konya ve çevresinde göllerin alanı SBM'de en yüksek seviye ulaşmış ve sedimantasyon artmıştır (Roberts, 1983). Bu sahalarda günümüzde aylık ortalama sıcaklıklar y1l boyunca $0{ }^{\circ} C^{\prime}$ 'n altına inmezken, CCSM4 verilerine göre SBM'de 3-4 ay $0{ }^{\circ} \mathrm{C}$ 'ın altında kalmış, yağış ise artmıştır. Bu değişim, buharlaşmayı düşürmekte, kış aylarında donmuş yüzeyler oluşturarak akışı engellemekte, yağış artışı ise daha fazla su kaynağı sağlamaktadır. Bahar ve yaz aylarında $0{ }^{\circ} \mathrm{C}$ 'ın üstüne çıkan sıcaklıklar, donmuş yüzeylerin çözülmesini ve akışı sağlamakta, buharlaşma miktarı günümüze göre düşük kalacağından göl seviyelerinin yükselmesi mümkün olabilmektedir. Bu bölge için, CCSM4 modeli tutarlı veriler sunsa da göl seviyesini kontrol eden sıcaklık-yağış olasılık eğrileri ortaya koyulabilirse, daha net bir karşılaştırma yapılabilecektir.

SBM'de Van Gölü seviyesinin 14-30 by arasında günümüze göre 145 ile 200 daha düşük olduğu anlaşılmıştır (Tomonaga vd., 2017). Modellemeler sonucunda Van Gölü güneyinde kalıcı kar seviyesinin günümüze göre 900-1250 m daha alçakta olduğu ve sıcaklığın ise 8 ile $11^{\circ} \mathrm{C}$ daha düşük 
olmas1 gerektiği belirtilmekte (Yeşilyurt, Doğan ve Akçar, 2018), CCSM4 verilerine göre de y1llık ortalama sıcaklıkların $10^{\circ} \mathrm{C}$ düşük olduğu görülmektedir. Van Gölü tabanından elde edilen verilere göre SBM'de Artemisia polen yoğunluğu artmakta, daha soğuk ve kurak bir iklimin hakim olduğu anlaş1lmaktadır (Litt vd., 2009; Stockheche vd., 2014). CCSM4 verilerine göre Van Gölü çevresi SBM'de günümüze göre daha az yağış almakta, yağış ve sıcaklık şartları açısından, daha soğuk ve kurak bir özellik göstererek, mevcut paleoklimatik veriler ve buzul araştırma sonuçları ile uyum göstermektedir. HEB sınıflandırmasındaki biyomlar değerlendirildiğinde, bu sahalar sslak ve nemli orman olarak görülmekte, buna rağmen yükselti ekolojik katları açısından yarı alpin ve alpin özellikler göstermekte, ağaç formasyonuna yetişmesine imkân vermemektedir. Bu sahada nemlilik durumunun buharlaşma-yağış oranı olarak düşünülmesi gerektiği, sıcaklık düşüşünün buharlaşmayı azaltarak, yağış miktarı düşse bile, su varlığını artırdığını, buna rağmen suyun daha çok katı halde saklandığını göstermektedir.

Atalay (1992) tarafından yapılan çalışmada, Akdeniz ve Ege kıyılarında kızılçam ve makiler olduğu belirtilmiş, CCSM4 verilerine göre bu bitki topluluğunun Adana Bölümü kıyıları ile Ege ve Akdeniz'e ulaşan akarsu vadi tabanlarında ve ovalarda görülen kurak orman biyomu sahalarında görülebileceği anlaşılmaktadır. Çalışmada, Karadeniz çevresi için belirlenen günümüze benzer türler ile İç Anadolu'daki stepler CCSM4 verilerinde de görülmüş, çölümsü stepler ise belirlenememiştir.

Yukarıdaki SBM için yapılan çoğu polen çalışmasında Artemisia polen yoğunluğu artışı, soğuk ve kurak ortam olarak tanımlansa da bu sahalar CCSM4 model verilerine göre oluşturulan HEB sınıflamasında daha nemli bölge özelliği göstermektedir. Bu durum, nemlilik tarifindeki farklılık ile ilişkilidir. Çoğu çalışmadaki kuraklık, günümüze göre daha az yağışıı olarak tarif edilmek istenmiş, bu dönemlerde sıcaklık da düştügünden klimatolojik olarak daha nemli ortamlar oluşmuştur. Artemisia'nın Karadeniz çevresinde de belirlenmesi, bu bitkinin kuraklıktan ziyade, daha yağışlı ama sıcaklığın düşük olduğu yerlerde de hâkim olabildiğini göstermekte, ekolojik şartlarının yağıştan çok, vejetasyon süresi ile ilişkili olduğunu ortaya koymaktadır. SBM'de vejetasyon süresinin kısaldığı ve yılın bir bölümünde toprağın donduğu, fizyolojik kuraklığın da ortaya çıktığı anlaşılmakta, bu bitki için de yağış kuraklığından çok fizyolojik kuraklığın hâkim olduğu, vejetasyon süresinin kısaldığı soğuk bölgelerde yayıldığı anlaşılmaktadır.

\section{Sonuç}

Bu çalışmada, günümüz iklimini yansıtan ERA-Interim verileri ile SBM'yi karakterize eden CCSM4 iklim modeli verileri incelenerek SBM' ile günümüz klimatolojik rejim farkl111kları değerlendirilmiştir. Çalışmada ayrıca, Türkiye'nin güncel ve SBM'deki HEB sınıfları karşıllaştırılmış, mekânsal dağılışları ortaya koyulmuştur. Elde edilen sonuçlar aşağıda maddeler halinde verilmiştir.

1-CCSM4 model verilerinde, SBM'de aylık ortalama sıcaklıklar tüm Türkiye'de günümüze göre daha düşüktür. Sıcaklık farkları Karadeniz çevresinde düşükken, güneye gidildikçe farklar artmaktadır. En yüksek sıcaklık farkları Güneydoğu Anadolu Bölgesinde görülmektedir. S1caklık farkları, kuraklığa bağlı olarak artmaktadır. SBM'de Türkiye genelinde en yüksek sıcaklıklar temmuz ayında, en düşük sıcaklıklar ise Çanakkale Boğazı çevresinde aralık, diğer bölgelerde ocak ayına denk gelmektedir. 
2-CCSM4 verilerine göre SBM'de Doğu Anadolu Bölgesinde, Güneydoğu Toroslarda, deniz kıyılarında ve nispeten alçak bölgelerde günümüze göre daha düşük yağışlar varken, dağlık alanlardaki yağışlar daha yüksektir. SBM'de çok zirveli (düzenli) yağış rejimi daha geniş, tek zirveli (Akdeniz) yağış rejimi daha dar alan kaplamaktayken, Güneydoğu Anadolu Bölgesinde çift zirveli (karasal) rejim hâkim durumdadır. En kurak ve yağışlı aylarda mekânsal değişimler görülmektedir.

3- CCSM4 model verilerine göre SBM'de Türkiye'de alçak irtifa kuşağı bulunmazken, dağönü kuşağı sadece Ege, Akdeniz ve Karadeniz kıyılarına sıkışmaktadır. Dağlık kat, Türkiye'nin batısına doğru hareket etmekte ve daha geniş alan kaplamaktadır. SBM'de Doğu Anadolu Bölgesinin büyük bölümü yarıalpin ve alpin kattan oluşmakta, Doğu Karadeniz Dağları ile yüksek dağların zirve çevrelerindeki karlı kat hâkim olmaktadır.

4- SBM'de HEB nemlilik sınıflarından yarı kurak ve yarı nemli alanlar günümüze göre daha dar alan kaplarken, nemli, çok nemli, aşırı nemli, yarı doygun, yüksek doygun ve tam doygun sahalar daha geniş sahalarda hâkimdir. Yarı kurak sahalar sadece Güneydoğu Anadolu Bölgesinin güneyinde görülmekte, İç Anadolu Bölgesinde ise yarı nemli sahalar yer almaktadır. CCSM4 verilerine göre SBM'de dağlık alanlarda, aşırı nemli sahalar genişlemiş, bu sahaların yüksek kesimlerinde farklı özellikte doygun alanlar oluşmuştur.

5- Günümüzde Türkiye'de bulunan çöl çalılığı ve dikenli çalılıklar SBM'de bulunmamakta, Eleşkirt Ovası'nda çok dar bir alanda ise günümüzde görülmeyen kurak çalılık sahası ortaya çıkmaktadır. SBM'de dikenli çalılıklar, stepler ve kurak ormanlar günümüze göre daha darken, nemli ve ıslak ormanlar, sslak ve yağmurlu tundralar ile soğuk çöl biyomları ve buzul alanları geniş alan kaplamaktadır. Yağmur ormanları SBM'de daralmakta, dağlık yağmur ormanları genişlemektedir.

6-CCSM4 verilerine göre SBM'de günümüzde görülen tümleşik HEB sınıflarından 34'ünün alanının arttığı, 16'sının azaldığı görülmüş, 13 sınıfın SBM'de bulunmadığı, 8 sınıfın ise SBM'de bulunurken günümüzde Türkiye'nin hiçbir yerinde görülmediği anlaşılmıştır.

7-CCSM4 verileri kullanılarak oluşturulan HEB sınıfları ile paleoklimatolojik ve buzul çalışma sonuçları karşılaştırıldığında, verilerin Türkiye'nin doğu yarısında tutarlı olduğu, Güney Marmara, Antalya Körfezi kuzeyi ve doğusu ile Menteşe Dağlık alanı çevresinde ise yeterli buzullaşmayı oluşturamadığı görülmüştür. Tutarlılığın düşük olduğu sahalarda, ya CCSM4 verilerinin SBM'deki yağışı daha düşük ve özellikle Uludağ çevresindeki sıcaklıkları da daha yüksek göstermesi ya da HEB sınıflarının buzul sahalarını tam tanımlayamamasından kaynaklanmaktadır. 


\begin{tabular}{ccc} 
Coğrafi Bilimler Dergisi & Cografi \\
Bilimler & Dergisi \\
\hline
\end{tabular}

\section{Holdridge Ecological Zones of Turkey in Last Glacial Maximum (LGM) using High Resolution CCSM4 Model Data and Comparison of Current Climate Conditions}

Erkan Y1lmaz*a

\section{EXTENDED ABSTRACT}

\section{Introduction}

In this study, environmental conditions during the Last Glacial Maximum (LGM) in Turkey were examined by creating Holdridge ecological zones (HEZ) using the CCSM4 climate model data (Gent et al., 2011). Here, ambient conditions in the LGM are also compared with current HEZ zones (Y1lmaz, 2021) created by ERA-Interim data (Dee et al., 2011) with an enhanced resolution by Karger et al. (2017). The average monthly temperature and total monthly precipitation amounts were also compared, the differences were determined, and changes in precipitation and temperature regimes were revealed.

\section{Method}

A variety of model data of the LGM and CCSM4 is used more frequently both on a global scale and in Turkey for paleoenvironmental studies (Brady et al., 2013; Feng et al. 2017; Gent et al., 2011; Meehl and Arblaster, 2011; Çoban, Örücü and Arslan, 2020; Sarıkaya et al., 2018). In this study, monthly average temperature and monthly total precipitation data with a resolution of $1 \mathrm{~km}$ were evaluated and HEZ zone was performed using the method reported by Yilmaz (2021). In the HEZ method, Potential evapotranspiration (PE) values are used, which are calculated for the temperature range $0-30^{\circ} \mathrm{C}$. Since some points in the LGM (e.g., Mount Ararat peak) have temperatures below $0^{\circ} \mathrm{C}$ throughout the year, the PE value in these areas could not be calculated; thus, its definition in the graph was not possible. In the present study, these fields were described as nival, saturated, and glacial field. Vector formats of HEZ zones of Turkey produced in the study can be downloaded from http://geography.humanity.ankara.edu.tr/turkiye-iklim-arastirmalari/.

\section{Result and Discussion}

Based on CCSM4 model data, the differences in monthly average temperatures determined for LGM and current averages decrease toward the north of Turkey and exceed $10^{\circ} \mathrm{C}$ in the Southeastern Anatolian region. Given that humidity conditions around the Black Sea are high, we may conclude that the differences vary depending on humidity conditions. In areas where the relative humidity is high, the

\footnotetext{
* Corresponding Author: eryilmaz@ankara.edu.tr

a Ankara University, Department of Geography, Ankara/Turkey, http://orcid.org/ 0000-0002-3821-3648.
} 
temperature difference is lower than that in other areas. A similar event can be seen in the results of the climate model that predicts that the future temperature increases will be higher in the Southeastern Anatolia region (Akçakaya et al., 2015; Önol and Semazzi, 2009).

In the LGM, theoretically, the coldest and warmest periods are expected to change according to the present day and the solstices and equinox times are expected to shift depending on precession. Depending on this movement, the hot and cold months should coincide only in $\sim 26000$ years (Moebs, Ling and Sanny, 2016) and change at other times. However, the differences were determined in the model data in a narrow area (the coldest month coinciding with December in Thrace), which did not significantly change in the hottest and coldest months. In the LGM, change in the warmest and coldest periods depend on precession, as reflected in a small area in Turkey. Thus, the lack of change is due to the fact that the present-day state of precession (completion of the cycle) is temporally close to the LGM. It may also be possible that the model capability does not adequately reflect this movement parameter.

Laskar et al. (2011) defined eccentricity as the ratio of the difference between the axis lengths of the ellipse to the sum of axes of the ellipse expressed as orbital kurtosis ratio. Presently, this ratio is defined as 0.016702, while in the LGM, it is 0.019223. A high kurtosis rate in the LGM causes the closest position from the Sun to be closer than that of today and the farthest position to be farther than that of today. Since the axis tilt at LGM is lower than $23^{\circ}$, it should have caused the Sun's rays to be high in winter and low in summer during the equinox periods, reducing the energy budget difference between the winter and summer seasons compared to today. It is understood that this, in turn, will increase seasonal variability.

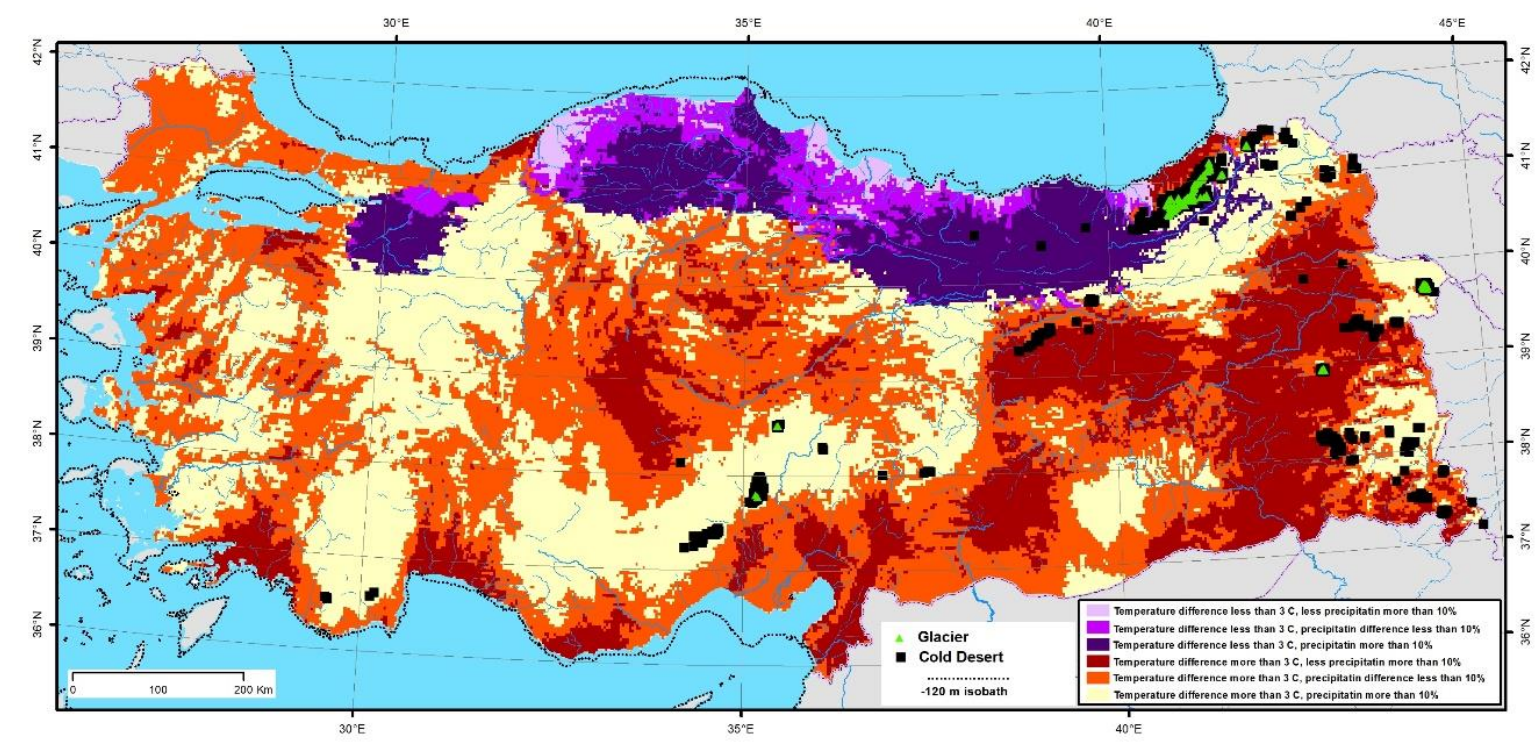

Figure 1. Comparison of temperature and precipitation differences in LGM according to CCSM4 data, sea and lake levels in LGM according to GEBCO (2020) data and glacial and cold desert points from HEZ zones.

Mountainous areas where precipitation has changed compared to that of today receive high precipitation in the LGM, whereas coasts and low-altitude areas get low precipitation and the Black Sea and Marmara show a lake feature (Figure 1, -120 equal depth curve). High precipitation in mountainous 
areas is thought to be associated with reducing temperatures and low condensation level during this period.

According to CCSM4 data in the LGM, glacial areas were determined in Eastern Black Sea Mountains, Ağrı (Ararat), Süphan, Erciyes, and Aladağlar (Niğde), and cold desert areas are formed in Cilo, Mengene, İhtiyarşahap, Tendürek, Karçal, Yalnızçam, Giresun, Munzur, Bolkar Mountains, Akdağlar, Bey Mountains, Hasan Mountain, South Aras Mountains, Tahtalı, Berit, Nurhak, Keşiş, and Mescit Mountains (Figure 2). Despite this, rain tundra or rain forest (paramo) have been identified in Uludağ, Barla, Davraz, Dedegöl, Sandıras, Honaz, and Geyik Mountains where glaciers have been detected in the LGM (Sarıkaya et al., 2011).
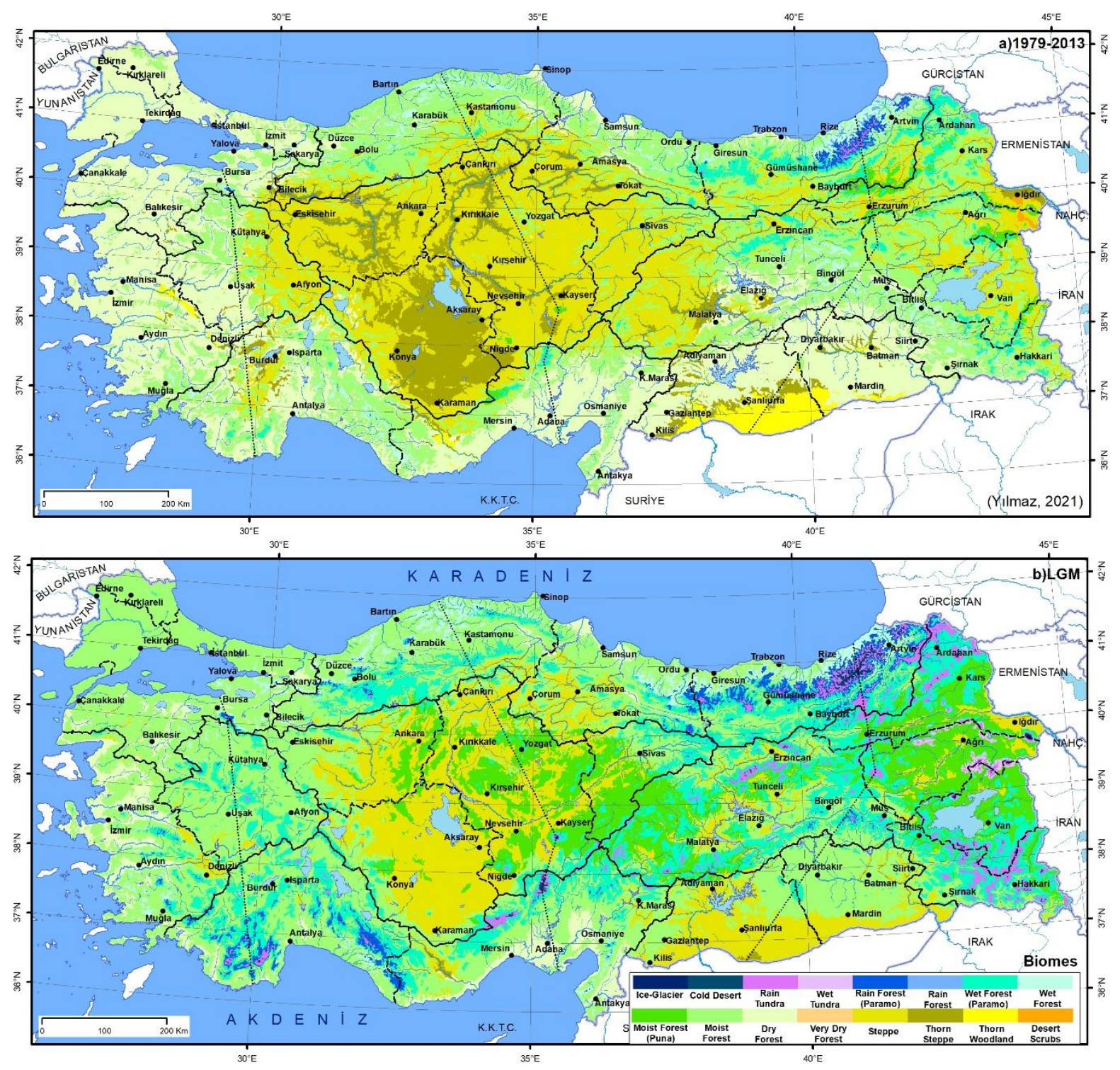

Figure 2. Current and the LGM biome distribution in Turkey.

Compared to today's and LGM HEZ biomes, similar biomes were found in the Eastern and Western Black Sea environment, including the mountainous areas of Uludağ, Sündiken, Köroğlu, and 
Ilgaz. In the temperature data modeled for these areas, the average annual temperature differences between LGM and today are less than $3^{\circ} \mathrm{C}$ (Figure 1). Similarly, in these mountainous areas, precipitation is either similar to today or falls further. Although this reduces the PE rate that can be calculated for these sites, it causes the biome to remain the same and does not exceed the limit of biome change in HEZ zones.

In a seafloor drilling conducted off Samsun in the Black Sea, it was observed that pollen of the steppe type characterizes arid conditions around the Black Sea between 64-20 ky. (Shumilovskikh et al., 2014), although humidity conditions are increased by $28-20 \mathrm{ky}$. This partially coincides with CCSM4 data; although there is a colder and less rainy environment around the Black Sea in LGM, wetter conditions prevail.

In the LGM, lake levels in central and western Anatolia rose; the area of lakes in and around Konya reached the highest level in LGM, and sedimentation increased (Erol, 1971,1995; Kashima, 2002; Roberts, 1983). In these areas, average monthly temperatures do not fall below $0^{\circ} \mathrm{C}$ during the year, while according to CCSM4 data, LGM has remained below $0^{\circ} \mathrm{C}$ for $3-4$ months and precipitation has increased.

In the LGM, the level of Lake Van at 14-30 ky. is 145-200 m. lower than that of today (Tomonaga et al., 2017). As a result of modeling, it is stated that the permanent snow level in the south of Lake Van is $900-1250 \mathrm{~m}$ lower and temperature should be $8-11^{\circ} \mathrm{C}$ lower than that of today (Yeşilyurt, Doğan ve Akçar, 2018). According to CCSM4 data, the average annual temperature is $10^{\circ} \mathrm{C}$ lower. Based on data obtained from the base of Lake Van, the density of Artemisia pollen increases in LGM and a cold and dry climate prevails (Litt et al., 2009; Stockheche et al., 2014). According to CCSM4 data, the environment of Lake Van receives less precipitation in LGM than that received today, showing a cold and dry feature based on existing paleoclimatic data and glacial research results.

Determination of Artemisia around the Black Sea also shows that this plant can prevail in places where it is more humid but has low temperature rather than in drought areas, indicating that its ecological conditions are more associated with vegetation duration than precipitation. In the LGM, the vegetation period is shortened and the soil freezes during a part of the year; and more physiological drought prevails than precipitation drought. It is understood that it spreads in cold areas where the vegetation period is shortened.

\section{Conclusion}

1. In CCSM4 model data, monthly average temperatures in the LGM are lower than that of today in entire Turkey. While temperature differences are low around the Black Sea, the differences increase toward the south and the highest temperature differences are observed in the Southeastern Anatolia region.

2. According to CCSM4 data, the LGM has lower precipitation in the Eastern Anatolia region, Southeastern Taurus Mountains, sea coasts of Turkey, and relatively low-altitude regions than that of today, whereas precipitation received in mountainous areas is higher. 
3. According to CCSM4 model data, the LGM does not have a low-altitude zone in Turkey, whereas the premontane zone is stuck only on the Aegean, Mediterranean, and the Black Sea coasts. The montane zone enlarges to the west of Turkey and covers a larger area.

4. In the LGM, semi-arid and sub-humid areas of HEZ humidity regions cover a narrow area than that of today, while humid, per-humid, super-humid, semi-saturated, sub-saturated, and saturated areas dominate large areas. Semi-arid areas are only visible in the Southeastern Anatolia region, while sub-humid areas are located in the Central Anatolia region. According to CCSM4 data, extremely humid areas have expanded in mountainous areas of the LGM, and saturated areas of different characteristics are formed in high regions of these areas.

5. In Turkey, Desert shrubs and thorny woodland are not defined in the LGM. Thorny woodland, steppes, and dry forests are narrower than that of today, while moist and wet forests, wet and rain tundra, cold desert biomes, and glacial areas cover large areas. Rainforests are shrinking in the LGM, while rain forests paramo are expanding.

6. According to CCSM4 data, 34 of the integrated HEZ zones defined today in LGM have enlarged, 16 zones have narrowed, 13 zones do not exist, and 8 zones are located in LGM; however, today, they are not visible anywhere in Turkey.

7. Compared the palaeoclimatological and glacial study results with the HEZ zones using CCSM4 data, it was found that the data were consistent in the eastern half of Turkey.

\section{Referanslar/References}

Akçakaya, A., Sümer, U. M., Demircan, M., Demir, Ö., Atay, H., Eskioğlu, O., Çukurçayır, F. (2015). Yeni Senaryolar ile Türkiye İklim Projeksiyonlart ve İklim Değişikliği. Ankara: Meteoroloji Genel Müdürlüğü.

Atalay, İ. (1984). Mescit Dağının Glasyal Morfolojisi, Ege Coğrafya Dergisi, 2, 31-48. https://dergipark.org.tr/tr/pub/ecd/issue/4892/67072

Atalay, İ. (1992). The Paleogeography of Near East and Human Impact. İzmir: Ege University Press.

Atalay, İ. (2005). Kuvaterner'deki iklim değişmelerinin Türkiye doğal ortamı üzerindeki etkileri. Türkiye Kuaterner Sempozyuтu (TURQUA -V) içinde (ss. 121-128). İstanbul: İTÜ Avrasya Yer Bilimleri Enstitüsü.

Atalay, İ. (1994). Türkiye Vejetasyon Coğrafyası. İzmir: Ege Üniversitesi Basımevi.

Atalay, İ. (1996). Palaeosols as indicators of the climatic changes during Quaternary period in S. Anatolia. Journal of Arid Environments, 32 (1), 23-35. doi:10.1006/jare.1996.0003

Bayrakdar, C., Çılgın, Z., Döker, M. F., Canpolat, E. (2015). Evidence of an active glacier in the Munzur Mountains, Eastern Turkey. Turkish Journal of Earth Sciences, 24 (1), 56-71. doi:10.3906/yer-1403-7

Berger, A., Crucifix, M., Hodell, D. A., C.Mangili, F.McManus, J., B.Otto-Bliesner, E.W.Wolff2, Q. Z.Yin1, A.Abe-Ouchi8, C.Barbante9, V.Brovkin10, I.Cacho11, E. Capron5, P. Ferretti9, A.Ganopolski12, J.O, N. V. R. (2016). Interglacials of the last 800,000years. Reviews of Geophysics, 54, 162-219. doi:doi:10.1002/2015RG000482

Brady, E. C., Otto-Bliesner, B. L., Kay, J. E., Rosenbloom, N. (2013). Sensitivity to glacial forcing in the CCSM4. Journal of Climate, 26 (6), 1901-1925. doi:10.1175/JCLI-D-11-00416.1

Brauer, A., Haug, G. H., Dulski, P., Sigman, D. M., Negendank, J. F. W. (2008). An abrupt wind shift in western Europe at the onset of the Younger Dryas cold period. Nature Geoscience, 1 (8), 520-523. doi:10.1038/ngeo263

Çiner, A., Sarıkaya, M. A. (2013). Buzullar ve iklim değişikliği: Geçmiş, günümüz ve gelecek. Volkan Ş. Ediger (Ed.), Türkiye'de İklim Değişimi ve Sürdürülebilir Enerdi içinde (s. 19-89). İstanbul: ENIVA-Enerji ve İklim Degişikligi Vakfi.

Çiner, A., Sarıkaya, M. A. (2017). Cosmogenic 36Cl geochronology of late Quaternary glaciers in the Bolkar Mountains, south central Turkey. Geological Society Special Publication içinde (C. 433, s. 271-287). Geological Society of London. 
doi:10.1144/SP433.3

Clark, P. U., Mix, A. C. (2002). Ice sheets and sea level of the Last Glacial Maximum. Quaternary Science Reviews, 21 (1-3), 1-7. doi:10.1016/S0277-3791(01)00118-4

Çoban, H. O., Örücü, Ö. K., Arslan, E. S. (2020). Maxent modeling for predicting the current and future potential geographical distribution of Quercus Libani Olivier. Sustainability (Switzerland), 12 (7), 1-17. doi:10.3390/su12072671

Cohen, K. M., Gibbard, P. L. (2019). Global chronostratigraphical correlation table for the last 2.7 million years. Quaternary International, 31 (2), 20-31. doi:10.1016/j.quaint.2019.03.009

Cox, C. B., Healey, I. N., Moore, P. D. (1977). Biogeography: An Ecological and Evolutionary Approach.Systematic Botany (C. 2). Oxford: Wiley-Blackwell. doi:10.2307/2418264

Dee, D. P., Uppala, S. M., Simmons, A. J., Berrisford, P., Poli, P., Kobayashi, S., Vitart, F. (2011). The ERA-Interim reanalysis: Configuration and performance of the data assimilation system. Quarterly Journal of the Royal Meteorological Society, 137 (656), 553-597. doi:10.1002/qj.828

Doğu, A. F. (1993). Sandıras dağında buzul şekilleri. Türkiye Coğrafyası Araştırma ve Uygulama Merkezi Dergisi, 2, 263274.

Doğu, A. F., Çiçek, İ., Gürgen, G., Tunçel, H. (1996). Üçdoruk (Verçenik) Dağında buzul şekilleri, yaylalar ve turizm. Türkiye Cografyası Ar. ve Uy. Mer. Der., 5, 29-52.

Doğu, A. F., Somuncu, M., Çiçek, İ., Tunçel, H., Gürgen, G. (1993). Kaçkar Dağında buzul şekilleri, yaylalar ve turizm. Türkiye Coğrafyast Ar. ve Uy. Mer. Der., 2, 157-184.

Dufresne, J. L., Foujols, M. A., Denvil, S., Caubel, A., Marti, O., Aumont, O., ... Vuichard, N. (2013). Climate change projections using the IPSL-CM5 Earth System Model: From CMIP3 to CMIP5. Climate Dynamics (C. 40). doi:10.1007/s00382-012-1636-1

Eastwood, W. J., Roberts, N., Lamb, H. F., Tibby, J. C. (1999). Holocene environmental change in southwest Turkey: a palaeoecological record of lake and catchment-related changes. Quaternary Science Reviews (C. 18).

Erinç, S. (1977). Vejetasyon Coğrafyası. İstanbul: İstanbul Üniversitesi Yayınları.

Erinç, S. (2001). Jeomorfoloji II. İstanbul: Der Yayınları.

Erlat, E. (1999). El Nino, La Nina ve Güneyli Salınım. Ege Coğrafya Dergisi, 10, $125-148$. https://dergipark.org.tr/tr/pub/ecd/issue/4884/66965

Erol, O. (1971). Konya, Tuzgölü, Burdur Havzalarındaki pluvial göllerin çekilme safhalarının jeomorfolojik delilleri. Coğrafya Araştırmaları Dergisi, 3-4, 13-52. http://tucaum.ankara.edu.tr/wp-content/uploads/sites/280/2015/08/cadcae3-4_2.pdf

Erol, O. (1995). Anadoluda Kuaterner plüvyal ve interplüvyal koşullar ve özellikle güney-İç Anadoluda son buzul çağından bugüne kadar olan çevresel değişimler. Coğrafya Araştırmaları Dergisi, 9 (2), 5-16. http://tucaum.ankara.edu.tr/wpcontent/uploads/sites/280/2015/08/cadcae9_2.pdf

Fairbanks, R. G. (1989). A 17,000-year glacio-eustatic sea level record: Influence of glacial melting rates on the Younger Dryas event and deep-ocean circulation. Nature, 342(6250), 637-642. doi:10.1038/342637a0

Feng, S., Trnka, M., Hayes, M. ve Zhang, Y. (2017). Why do different drought indices show distinct future drought risk outcomes in the U.S. Great Plains? Journal of Climate, 30 (1), 265-278. doi:10.1175/JCLI-D-15-0590.1

Fleming, K., Johnston, P., Zwartz, D., Yokoyama, Y., Lambeck, K., Chappell, J. (1998). Refining the eustatic sea-level curve since the Last Glacial Maximum using far- and intermediate-field sites. Earth and Planetary Science Letters, 163 (1-4), 327-342. doi:10.1016/S0012-821X(98)00198-8

Fuhrer, K., Wolff, E. W., Johnsen, S. J. (1999). Timescales for dust variability in the Greenland Ice Core Project (GRIP) ice core in the last 100,000 years. Journal of Geophysical Research Atmospheres (C. 104). doi:10.1029/1999JD900929

GEBCO. (2020). GEBCO data download. 13 Kasım 2020 tarihinde https://download.gebco.net/ adresinden alınd1.

Gent, P. R., Danabasoglu, G., Donner, L. J., Holland, M. M., Hunke, E. C., Jayne, S. R., ... Zhang, M. (2011). The community climate system model version 4. Journal of Climate, 24 (19), 4973-4991. doi:10.1175/2011JCLI4083.1

Gürgen, G. (2003). Çapans Dağları kuzeyinin (Rize) glasyal morfolojisi. Gazi Eğitim Fakültesi Dergisi, 3 (2003), 159-175. http://www.gefad.gazi.edu.tr/tr/pub/issue/6761/90954

Gürgen, G. (2006). Üçdoruk-Dilek Dağları güneyinin glasyal morfolojisi. Coğrafi Bilimler Dergisi, 4 (2), 67-82. doi: 10.1501/Cogbil_0000000069 
Gürgen, G. (2009). Anzer-Kemer-Orsor Dağları kuzeyinin (Rize) glasyal morfolojisi. e-Journal of New World Sciences Academy. 4 (4), 175-190. https://dergipark.org.tr/tr/pub/nwsanature/issue/10853/130557

Gürgen, G. (2015). Tatos Gediği Buzulu (Rize). Coğrafi Bilimler Dergisi, 13 (2), 161-171. doi: 10.1501/Cogbil_0000000169

Gürgen, G. (2016). Çinaçor Buzulu (Tatos Dağları). Coğrafi Bilimler Dergisi, 14 (1),57-69. doi: 10.1501/Cogbil_0000000173

Gürgen, G. (2019). Çatakkaya Döküntü Örtülü Buzulu (Tatos Dağları). Coğrafi Bilimler Dergisi, 17 (1), 217-236.doi: 10.33688/aucbd.536616

Gürgen, G., Çalışkan, O., Yılmaz, E., Yeşilyurt, S. (2010). Yedigöller Platosu ve Emli Vadisinde (Aladağlar) döküntü örtülü buzullar. e-Journal of New World Sciences Academy, 5 (2), 98-116.

Gürgen, G., Çalışkan, O., Yılmaz, E., Yeşilyurt, S. (2012). Bolkar Dağları kuzeydoğusunun glasyal morfolojisi ve döküntüyle örtülü buzulları. Uluslararası İnsan Bilimleri Dergisi, 9 (1), 890-911. https://core.ac.uk/download/pdf/268072694.pdf

Hayes, A., Kucera, M., Kallel, N., Sbaffi, L., Rohling, E. J. (2005). Glacial Mediterranean sea surface temperatures based on planktonic foraminiferal assemblages. Quaternary Science Reviews, 24, 999-1016. doi:10.1016/j.quascirev.2004.02.018

Holdridge, L. R. (1947). Determination of world plant formations from simple climatic data. Science, 105(2727), 367-368. doi:10.1126/science.105.2727.367

Jouzel, J., Masson-Delmotte, V., Cattani, O., Dreyfus, G., Falourd, S., Hoffmann, G., ... Wolff, E. W. (2007). Orbital and millennial antarctic climate variability over the past 800,000 years. Science, 317 (5839), 793-796. doi:10.1126/science. 1141038

Jungclaus, J. H., Fischer, N., Haak, H., Lohmann, K., Marotzke, J., Matei, D., .. Von Storch, J. S. (2013). Characteristics of the ocean simulations in the Max Planck Institute Ocean Model (MPIOM) the ocean component of the MPI-Earth system model. Journal of Advances in Modeling Earth Systems, 5 (2), 422-446. doi:10.1002/jame.20023

Karger, D. N., Conrad, O., Böhner, J., Kawohl, T., Kreft, H., Soria-Auza, R. W., ... Kessler, M. (2017). Climatologies at high resolution for the earth's land surface areas. Scientific Data, 4 (1), 1-20. doi:10.1038/sdata.2017.122

Kashima, K. (2002). Environmental and climatic changes during the last 20000 years at Lake Tuz, central Turkey. Catena, 48, 3-20. doi: 10.1016/S0341-8162(02)00006-1

Kashima, K. (2003). The quantitative reconstruction of salinity changes using diatom assemblages in inland saline lakes in the central part of Turkey during the late Quaternary. Quaternary International, 105 (2003), 13-19. doi:Pii S10406182(02)00145-3

Kurter, A. (1991). Glaciers of Middle East and Africa-Glaciers of Turkey, Satellite Image Atlas of the World. USGS Professional Paper 1386-G-1.

Laskar, J., Fienga, A., Gastineau, M., Manche, H. (2011). La2010: A new orbital solution for the long-term motion of the Earth. Astronomy and Astrophysics, 532, 1-15. doi:10.1051/0004-6361/201116836

Leemans, R. (1990). Possible changes in natural vegetation due to a global warming. Global data sets collected and compiled by the Biosphere Project, Working Paper (C. Working Pa). Laxenburg, Austria: IIASA. doi:10.1017/cbo9780511525537.030

Lisiecki, L. E., Raymo, M. E. (2005). A Pliocene-Pleistocene stack of 57 globally distributed benthic $\delta 18 \mathrm{O}$ records. Paleoceanography, 20 (1), 1-17. doi:10.1029/2004PA001071

Litt, T., Krastel, S., Sturm, M., Kipfer, R., Örcen, S., Heumann, G., ... Niessen, F. (2009). "PALEOVAN", International Continental Scientific Drilling Program (ICDP): site survey results and perspectives. Quaternary Science Reviews, 28 (15-16), 1555-1567. doi:10.1016/j.quascirev.2009.03.002

Londeix, L., Herreyre, Y., Turon, J.-L., Fletcher, W. (2009). Last Glacial to Holocene hydrology of the Marmara Sea inferred from a dinoflagellate cyst record. Review of Palaeobotany and Palynology, 158, 52-71. doi:10.1016/j.revpalbo.2009.07.004

Major, C. O., Goldstein, S. L., Ryan, W. B. F., Lericolais, G., Piotrowski, A. M., Hajdas, I. (2006). The co-evolution of Black Sea level and composition through the last deglaciation and its paleoclimatic significance. Quaternary Science Reviews, 25, 2031-2047. doi:10.1016/j.quascirev.2006.01.032

Meehl, G. A., Arblaster, J. M. (2011). Decadal variability of Asian-Australian monsoon-ENSO-TBO relationships. Journal of Climate, 24 (18), 4925-4940. doi:10.1175/2011JCLI4015.1

Miebach, A., Niestrath, P., Roeser, P., Litt, T. (2016). Impacts of climate and humans on the vegetation in northwestern Turkey: Palynological insights from Lake Iznik since the Last Glacial. Climate of the Past, 12 (2), 575-593. doi:10.5194/cp-12575-2016 
Moebs, W., Ling, S. J., Sanny, J. (2016). Precession of a Gyroscope - University Physics Volume 1 | OpenStax. 11 Şubat 2021 tarihinde https://openstax.org/books/university-physics-volume-1/pages/11-4-precession-of-a-gyroscope adresinden erişildi.

Mudie, P. J., Marret, F., Aksu, A. E., Hiscott, R. N., Gillespie, H. (2007). Palynological evidence for climatic change, anthropogenic activity and outflow of Black Sea water during the late Pleistocene and Holocene: Centennial- to decadalscale records from the Black and Marmara Seas. Quaternary International, 167-168, 73-90. doi:10.1016/j.quaint.2006.11.009

Önol, B., Semazzi, F. H. M. (2009). Regionalization of climate change simulations over the Eastern Mediterranean. Journal of Climate, 22 (8), 1944-1961. doi:10.1175/2008jcli1807.1

Ozalp, I., Caner, H., Kilic, N. K., Avci, M. (2017). Analysis of fossil pollen record from the Late Holocene in the Turkish Highland (Middle Taurus,Turkey). Ecological Questions. doi:10.12775/EQ.2017.022

Paillès, C., Blanc-Valleron, M. M., Poulin, M., Crémière, A., Boudouma, O., Pierre, C. (2014). Entomoneis calixasini sp. nov., a new fossil diatom from the Turkish Marmara Sea sediments. Diatom Research, 29 (4), 411-422. doi:10.1080/0269249X.2014.921645

Petit, J. R., Jouzel, J., Raynaud, D., Barnola, J. M., Basile, I., Bender, M., ... Stievenard, M. (2013). Climate and atmospheric history of the past 420,000 years from the Vostok ice core, Antarctica. The Future of Nature: Documents of Global Change, 348-358. doi: 10.1038/20859

Roberts, N. (1983). Age, palaeoenvironments, and climatic significance of late Pleistocene Konya lake, Turkey. Quaternary Research, 19 (2), 154-171. doi:10.1016/0033-5894(83)90002-9

Roberts, N. (2014). The Holocene (Third Edit.). Oxford: Wiley Blackwell. doi:10.2307/2261135

Ruddiman, W. F., Raymo, M., McIntyre, A. (1986). Matuyama 41,000-year cycles: North Atlantic Ocean and northern hemisphere ice sheets. Earth and Planetary Science Letters, 80 (1-2), 117-129. doi:10.1016/0012-821X(86)90024-5

Sarıkaya, M. A., Çiner, A., Haybat, H., Zreda, M. (2014). An early advance of glaciers on Mount Akdağ, SW Turkey, before the global Last Glacial Maximum; insights from cosmogenic nuclides and glacier modeling. Quaternary Science Reviews, 88, 96-109. doi:10.1016/j.quascirev.2014.01.016

Sarıkaya, M.A., Zreda, M., Çiner, A., Zweck, C. (2008). Cold and wet Last Glacial Maximum on Mount Sandıras, SW Turkey, inferred from cosmogenic dating and glacier modeling. Quaternary Science Reviews, 27 (7-8), 769-780. doi:10.1016/j.quascirev.2008.01.002

Sarıkaya, M. A., Çiner, A., Yıldırım, C. (2017). Cosmogenic $36 \mathrm{Cl}$ glacial chronologies of the Late Quaternary glaciers on Mount Geyikda $\mathrm{g}$ in the Eastern Mediterranean. Quaternary Geochronology, 39, 189-204. doi:10.1016/j.quageo.2017.03.003

Sarıkaya, M. A., Çiner, A., Zreda, M. (2011). Quaternary glaciations of Turkey. Developments in Quaternary Science, 15 (December), 393-403. doi:10.1016/B978-0-444-53447-7.00030-1

Sarıkaya, M. A., Zreda, M., Çiner, A. (2009). Glaciations and paleoclimate of Mount Erciyes, central Turkey, since the Last Glacial Maximum, inferred from 36Cl cosmogenic dating and glacier modeling. Quaternary Science Reviews, 28 (2324), 2326-2341. doi:10.1016/j.quascirev.2009.04.015

Sarıkaya, O., Karaceylan, I. B., Sen, I. (2018). Maximum entropy modeling (maxent) of current and future distributions of Ips mannsfeldi (Wachtl, 1879) (curculionidae: Scolytinae) in turkey. Applied Ecology and Environmental Research, 16 (3), 2527-2535. doi:10.15666/aeer/1603_25272535

Şenkul, Ç., Doğan, U. (2013). Vegetation and climate of Anatolia and adjacent regions during the Last Glacial period. Quaternary International, 302, 110-122. doi:10.1016/j.quaint.2012.04.006

Şenkul, Ç., Ören, A., Doğan, U., Eastwood, W. J. (2018). Late Holocene environmental changes in the vicinity of Kültepe (Kayseri), Central Anatolia, Turkey. Quaternary International, 486, 107-115. doi:10.1016/j.quaint.2017.12.044

Shumilovskikh, L. S., Fleitmann, D., Nowaczyk, N. R., Behling, H., Marret, F., Wegwerth, A., Arz, H. W. (2014). Orbital- and millennial-scale environmental changes between 64 and $20 \mathrm{ka} \mathrm{BP}$ recorded in Black Sea sediments. Climate of the Past, 10 (3), 939-954. doi:10.5194/cp-10-939-2014

Stockhecke, M., Sturm, M., Brunner, I., Schmincke, H. U., Sumita, M., Kipfer, R., ... Anselmetti, F. S.(2014). Sedimentary evolution and environmental history of Lake Van (Turkey) over the past 600000 years. Sedimentology, 61, 18301861.doi: $10.1111 /$ sed.12118

Stephens, G. L. (1990). On the relationship between water vapor over oceans and sea surface temperature. Journal of Climate, 3, 634-645. doi: 10.1175/1520-0442(1990)003<0634:OTRBWV>2.0.CO;2 
Svenning, J. C., Skov, F. (2004). Limited filling of the potential range in European tree species. Ecology Letters, 7 (7), $565-$ 573. doi:10.1111/j.1461-0248.2004.00614.x

Tarasov, P. E., Volkova, V. S., Webb, T., Guiot, J., Andreev, A. A., Bezusko, L. G., ... Sevastyanov, D. V. (2000). Last glacial maximum biomes reconstructed from pollen and plant macrofossil data from northern Eurasia. Journal of Biogeography, 27 (3), 609-620. doi:10.1046/j.1365-2699.2000.00429.x

Tomonaga, Y., Brennwald, M. S., Livingstone, D. M., Kwiecien, O., Randlett, M. E., Stockhecke, M., ... Kipfer, R. (2017). Porewater salinity reveals past lake-level changes in Lake Van, the Earth's largest soda lake, Sci Rep, 7 (1), 313. https://www.nature.com/articles/s41598-017-00371-w

Tonbul, S. (1997). Bingöl Dağında buzul şekilleri. Türkiye Coğrafyası Araştırma ve Uygulama Merkezi Dergisi, 6, $347-374$. http://tucaum.ankara.edu.tr/wp-content/uploads/sites/280/2015/08/tucaum6_17.pdf

Türkeş, M. (2010). Genel Klimatoloji. Ankara: Ertem Büro.

van Zeist, W., Bottema, S. (1982). Vegetational history of the eastern mediterranean and the near east during the last 20.000 years. International Series, 3 (February 2004), 277-371.

van Zeist, W., Woldring, H., Stapert, D. (1975). Late Qua- ternary vegetation and climate of southwestern Turkey. Palaeohistoria, 7, 53-143.

Voldoire, A., Sanchez-Gomez, E., Salas y Mélia, D., Decharme, B., Cassou, C., Sénési, S., ... Chauvin, F. (2013). The CNRMCM5.1 global climate model: Description and basic evaluation. Climate Dynamics, 40 (9-10), 2091-2121. doi:10.1007/s00382-011-1259-y

Watanabe, S., Hajima, T., Sudo, K., Nagashima, T., Takemura, T., Okajima, H., ... Kawamiya, M. (2011). MIROC-ESM 2010 : Model description and basic results of CMIP5-20c3m experiments. Geoscientific Model Development, 4 (4), 845-872. doi:10.5194/gmd-4-845-2011

Yalçınlar, İ. (1951). Soğanl1-Kaçkar ve Mescit Dağı silsilelerinin glasiasyon şekilleri. İstanbul Üniversitesi Edebiyat Fakültesi Coğrafya Bölümü Coğrafya Dergisi, 1 (2), 20-55.

Yeşilyurt, S. (2017). Kavuşşahap Dağları'nda (Van) Geç Kuvaterner Buzullaşması: Bölgesel Paleoiklim açısından bir değerlendirme. Ankara Üniversitesi, Sosyal Bilimler Enstitüsü, Basılmamış Doktora Tezi. https://tez.yok.gov.tr/UlusalTezMerkezi/tezSorguSonucYeni.jsp adresinden edinilmiştir.

Yeşilyurt, S., Doğan, U., Akçar, N. (2018). Narlıca Vadisi’nde geç Kuvaterner buzullaşma izleri, Kavuşşahap Dağları. Türk Coğrafya Dergisi, 70, 99-108. doi:19.17211/tcd.415232

Y1lmaz, E. (2021). Yüksek çözünürlüklü ERA-Interim ve HadGEM2-CC model verilerine göre Türkiye'nin güncel ve gelecekteki Holdridge ekolojik bölgeleri. Coğrafi Bilimler Dergisi, 19 (1), 29-60. doi: 10.33688/aucbd.778259

Yukimoto, S., Adachi, Y., Hosaka, M., Sakami, T., Yoshimura, H., Hirabara, M., ... Kitoh, A. (2012). A new global climate model of the Meteorological Research Institute: MRI-CGCM3: -Model description and basic performance-. Journal of the Meteorological Society of Japan, 90 (A), 23-64. doi:10.2151/jmsj.2012-A02

Zahno, C., Akçar, N., Yavuz, V., Kubik, P. W., Schlüchter, C. (2010). Chronology of Late Pleistocene glacier variations at the Uludağ Mountain, NW Turkey. Quaternary Science Reviews, 29 (9-10), 1173-1187. doi:10.1016/j.quascirev.2010.01.012

Zheng, W., Yu, Y. (2013). Paleoclimate simulations of the mid-Holocene and last glacial maximum by FGOALS. Advances in Atmospheric Sciences, 30 (3), 684-698. doi:10.1007/s00376-012-2177-6 